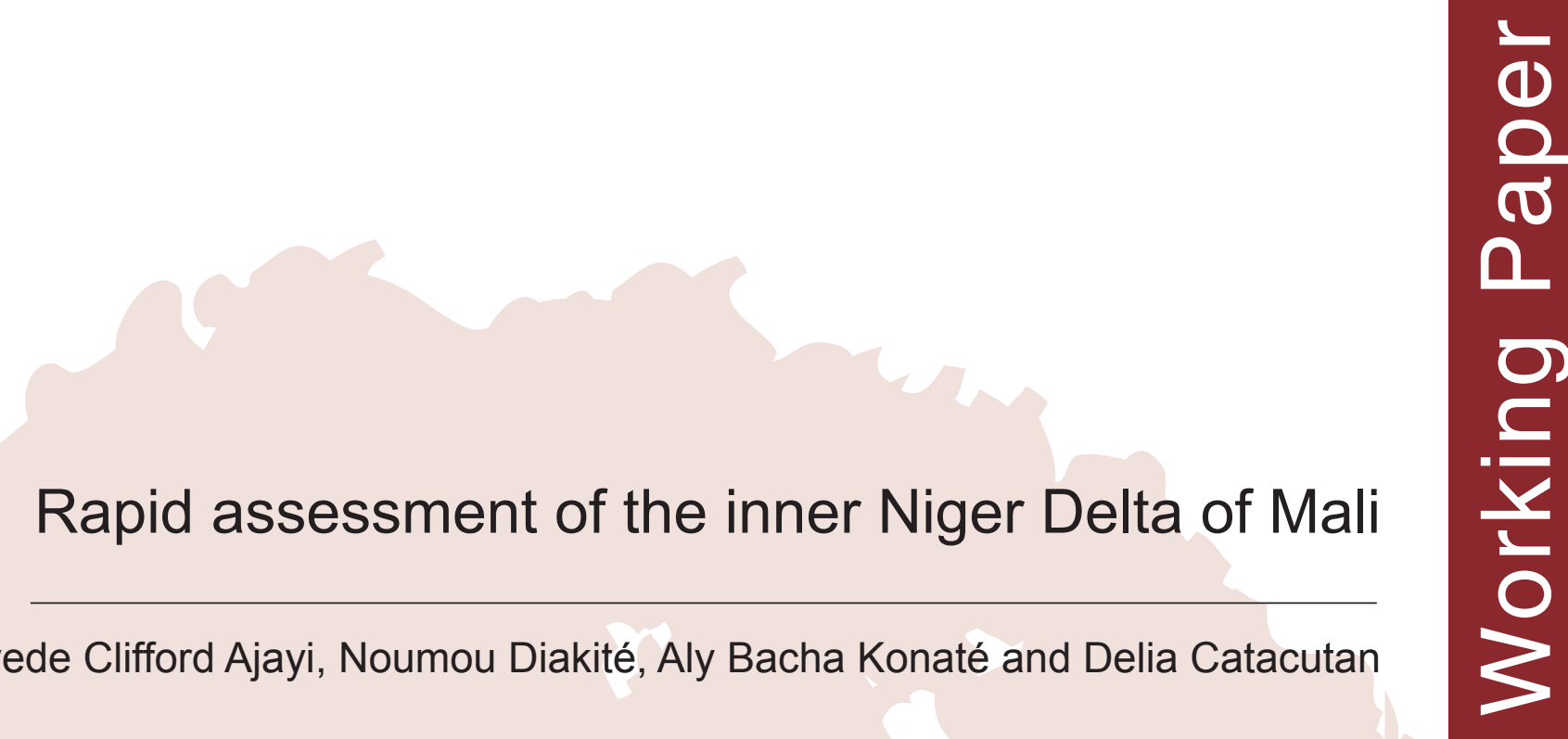

Oluyede Clifford Ajayi, Noumou Diakité, Aly Bacha Konaté and Delia Catacutan 


\section{Rapid assessment of the inner Niger Delta of Mali}

Oluyede Clifford Ajayi, Noumou Diakité, Aly Bacha Konaté and Delia Catacutan

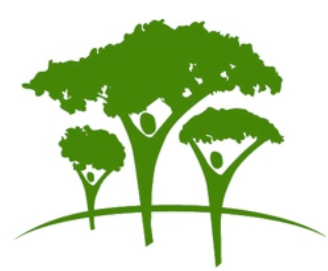

World Agroforestry Centre

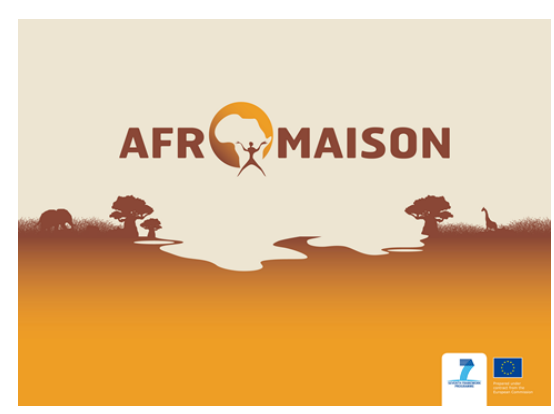




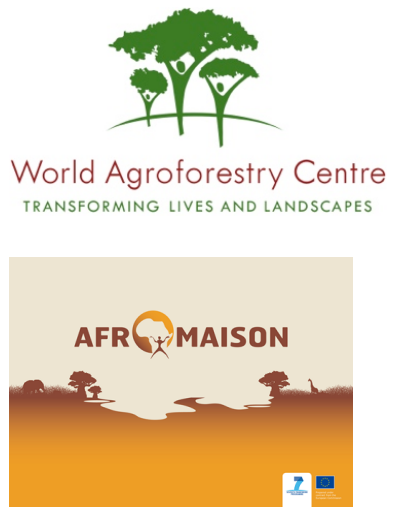

\section{LIMITED CIRCULATION}

Correct citation: Ajayi OC, Diakité N, Konate AB, Catacutan D. 2012. Rapid assessment of the inner Niger Delta of Mali. ICRAF Working Paper No 144. Nairobi: World Agroforestry Centre http://dx.doi.org/10.5716/WP12021.PDF

Titles in the Working Paper Series aim to disseminate interim results on agroforestry research and practices and stimulate feedback from the scientific community. Other publication series from the World Agroforestry Centre include Technical Manuals, Occasional Papers and the Trees for Change series.

Published by the World Agroforestry Centre

United Nations Avenue

PO Box 30677, GPO 00100

Nairobi, Kenya

Tel: $+254(0) 207224000$, via USA +1 6508336645

Fax: +254(0)20 7224001, via USA +1 6508336646

Email: worldagroforestry@cgiar.org

Website: www.worldagroforestry.org

(C) World Agroforestry Centre 2012 Working Paper No. 144

The views expressed in this publication are those of the author(s) and not necessarily those of the World Agroforestry Centre.

Articles appearing in this publication may be quoted or reproduced without charge, provided the source is acknowledged. No use of this publication may be made for resale or other commercial purposes.

All images remain the sole property of their source and may not be used for any purpose without written permission from the source.

The geographic designation employed and the presentation of material in this publication do not imply the expression of an opinion whatsoever on the part of the World Agroforestry Centre concerning the legal status of any country, territory, city or area or its authorities, or concerning the delimitation of its frontiers or boundaries. 


\section{ABOUT THE AUTHORS}

\section{Dr Oluyede Clifford Ajayi PhD}

Dr Oluyede Ajayi obtained a PhD in Agricultural \& Horticultural Economics at the University of Hannover in Germany. He is a senior scientist with the World Agroforestry Centre in Nairobi. An accomplished publisher and a Diamond Author Award Laureate, Dr Ajayi has carried out extensive research on natural resource management policies, food security climate change and payment for environmental services. He is an editorial board member for the International Journal of Agricultural sciences (Germany) and an occasional reviewer for several international journals.

\section{Dr Noumou Diakite PhD}

Dr Diakite is the Director of "Sahel Consult Mali" based in Sevaré-Mopti. He obtained a PhD in Veterinary Medicine from the Ecole Nationale Vétérinaire de Maisons Alfort in France. An experienced specialist in rural development, veterinary sciences and integrated natural resource management, Dr Diakité was the Director of Operations in the Mopti Region for 11 years. He has worked on rural development in several African countries including Mali, Niger, Burkina Faso, Côte d'Ivoire, Sénégal, Guinéa Conakry, Chad and Rwanda.

\section{Aly Bacha Konate}

Aly Konate is a graduate in Applied Sciences specializing in Forestry and Water Engineering. Since 1980, he has been working in rural development and management of renewable natural resources. He has held high-level positions in the public sector of Mali and NGOs and has authored several publications in forestry planning and management, institutional development and organizational strengthening, policy analysis and strategies for natural resource management. He is a member of the Committee Ramsar Wetland of the Inner Niger Delta of Mali, and the Network of Decentralized Management of Natural Resources.

\section{Dr Delia Catacutan PhD}

Dr Delia Catacutan is Social Scientist and Country Representative of the World Agroforestry Centre (ICRAF) for Viet Nam. She has over 10 years of experience in policy and institutional research in integrated natural resource management with numerous interdisciplinary research projects, including smallholder incentives and payments for ecosystems services; linking knowledge with action, institutional innovations, collective action and property rights, and technology adoption. Delia was a former Research Fellow of the Sustainability Science Programme at Harvard University's Centre for International Development. She has a PhD in Natural and Rural Systems Management from the University of Queensland, Brisbane, Australia. 


\section{EXECUTIVE SUMMARY}

This report was based on a study conducted under the auspices of the AFROMAISON project implemented by the World Agroforestry Centre (ICRAF) and its partners. The study aims at carrying out a rapid assessment through the collection and analysis of both qualitative and quantitative data of the Inland Niger Delta of Mali with the aim of contributing towards an improved and integrated management of natural resources in the Delta. The report is based on review of literature, field research and field survey interviews conducted with politicians, government technical services, NGOs, research and community organizations (farmers, pastoralists, fishermen). The data presented in this report were collected from the four "cercles" (administrative units) of Mopti region of the Delta. It does not include information on the Ké-Macina (Ségou region) and Niafunké, Diré and Goudam (Timbuktu region), which are also part of the Inland Niger Delta.

The report is divided into seven major parts: (i) Physical overview of the Inland Niger Delta; (ii) Demographic data giving the history and demographic characteristics of the people, food security situation, livelihood options and access to basic social services, social organization and main economic activities; (iii) Analysis of the political and legal systems of management of natural resources in the Delta; (iv) Major constraints and challenges faced by the population; (v) Main organizations and institutions responsible for natural resource management; (vi) Diagnostic tools and mechanisms for planning and management of natural resources and of prediction of flood water levels; (vii) Synthesis of lessons learnt and possible mitigation measures in the region.

The following are the main highlights of the study:

\section{Key challenges to natural resource management in the Inland Niger Delta}

- Changes in property rights, governance and population growth: one of the greatest challenges of natural resource management in the Delta is the presence of several interest groups (farmers, pastoralists and fishermen), and competition among the interest groups since the same land is used by fishermen (when there is flooding), farmers (to grow their crops) and pastoralists (searching for fodder when everywhere else is dried up). The competition for resources has increased tremendously as the population pressure becomes intense and traditional methods for managing relationships among the various groups in the Delta breaks down. Population pressure per se is not a problem but, the increase in population arising from both high natural birth rate and increased immigration from the Sahel regions to the Delta has increased competition among the different stakeholders. The super-imposition of different activities on the same piece of land (the same land is used by people who have 
different economic interests such as fishermen, farmers and pastoralists) at different times of the year has also led to conflicts over resource use. Due to climate change, the zone intervention by each ethnic group in the Delta has changed or has been re-defined but this has not been done to the satisfaction of all stakeholders, e.g. parts of the Delta that used to have floodwater used by fishermen has become too dry and are now being claimed as farmland or pasture land for livestock.

- Political interference and the breakdown of traditional methods that was used to manage the resources of the Delta among competing stakeholders have led to lack of respect of the transhumance routes. In some cases, the decentralization policy has partitioned the traditional jurisdiction of leaders since their traditional territories are now divided into different administrative structures over which they have no control. This has resulted in decreased influence of traditional leaders in the Delta. There is also a mushrooming number of traditional leaders exercising authority on natural resources in the Delta because of the entry fees and other levies collected from pastoralists which serve as a source of income all year round for these leaders.

- High human population growth rate and policies that focus on prioritizing food security to feed the rising population and which is perceived by other stakeholders as inadvertently favouring farmers. In many cases, in the quest for food production, the area delineated for transhumance has been converted to agricultural land.

- Increasing incidences of drought and climate change effects: drought degrades the traditional zone d'attente (a zone where livestock usually wait and feed to allow farmers harvest their crops before entering the Delta for pasture during the dry season). Drought leads to the drying up of watering points so livestock are tempted to enter the Delta without following the traditional calendar that regulates the entry of animals. This causes many conflicts between farmers and pastoralists.

\section{Socio-economic, biological and ecological importance of the Delta}

Almost all economic activities (agriculture, livestock, fishing, gathering, river transport, and energy production) revolve around these natural resources. The Delta ecosystem is the largest reservoir of biological diversity in Mali and even Africa. It was classified in February 2004 by UNESCO as a World Heritage Ramsar site for humanity. Its fauna consists of over 130 species of fish living next to aquatic mammals and reptiles. Regarding bird life, IND is one of the richest wetlands of West Africa, home to over 140 species of hundreds of thousands of African tropical and Eurasian birds. The flora is also very varied and there are several types of vegetation - 52 tree species and 137 species of grasses were counted in the forest. However, over the last 30 years, both the flora and fauna are in perpetual state of degradation due to the effects of drought caused by climate change and the high pressure exerted by human beings through timber harvesting, 
overgrazing, "over-fishing" and poaching. Thus, many animal and plant species and their habitats are currently threatened or endangered in the IND.

\section{Laws and regulations governing natural resource management in the Delta}

In principle, there is general awareness among government officials on the need to preserve and conserve natural resources. The legal texts that govern land, forests, wildlife and pasture are numerous in Mali. In terms of their strengths, the laws generally encourage all citizens to protect natural resources and the environment, ensure the right to access and use of resources in accordance with the standards set and in a spirit of justice and fairness, facilitate the principle of precaution with regard to environmental degradation caused by certain activities, and promote consultation and participation of stakeholders in the management of natural resources. However, the bane of these laws is that due to funding and human capital constraints, the level of field implementation is low and little has been done to translate these policies into concrete actions. In addition, some of the policies developed are contradictory. The multiplicity of the laws makes them difficult to implement and in some cases, the low compatibility of the texts of the laws with local realities, especially the ways and customs governing access and control of resources, remains a challenge. The strengths and weaknesses of the key ten national policies for natural resource management in Mali have been addressed in this study.

\section{Economic instruments and incentives to support natural resource management}

In recent years, the main stakeholders in the Delta are increasingly realizing the importance of the regulatory, provisioning and cultural values of the services provided by the ecosystems in the Delta region. There is an increasing appreciation that water and its natural resources are finite and communities have understood the crucial need to change human behaviour towards these resources. At the national level, apart from the "planting trees for self reliance", no economic incentive has been promoted at national level. However, at the local level, a number of NGOs support some economic incentive instruments and there are potential opportunities to support the Bioright approach where microcredit is combined with environmental services.

\section{Main structures and platforms to support natural resource management in the Delta}

Several key structures and platforms to support natural resource management exist in the Delta including public and private sector services, projects and programmes, and both regional and local NGOs. An analysis of the statutes, mandates and objectives including the achievements and challenges encountered by these institutions were carried out. The main challenges identified included the following: lack of mechanisms for consultation 
and coordination of their activities, thus experiences are not shared leading to unnecessary competition, and endless trial and errors and restarts. Several projects and organizations are involved in small-scale development projects, and often, there is lack of synergy as some NGOs are implementing similar activities in the same village. Further, many of these initiatives have a fairly short life span and do not have a long-term vision of natural resource management.

\section{Diagnostic tools and planning mechanisms for the management of natural resources}

Some diagnostic and prediction tools have been developed for the Delta in the past, and promoted by research institutions and international organizations such as IRD, AGRHYMET and Wetlands International, among others. These tools include SIMES, OPIDIN and SPIAC. However, many of them seem to be project-driven and their support platforms are built around a specific tool by the specific project that is promoting the tool. In many cases, when a project ends, activities to promote the tool also decreases as stakeholders wait for a new project and possibly a new tool. In some cases, the tools are in the experimental stage and have not been well validated, refined and disseminated to a wider audience of users due to the relatively short duration of some projects and funding constraints. As a result, their level of use in the field is still very limited. Dating from the colonial era, there has been a challenge with the reliability of some of the tools and instruments used for measuring the level of water and flooding in the Delta. Serious doubts are raised about the reliability of some diagnostic tools. For example, SPIAC under the control of AGHRYMET announced a good rainy season in 2011 but the season turned out to be one of the worst in terms of lack of rainfall and flooding of rivers. Interviews held with stakeholders revealed that some of the tools e.g. OPIDIN are quite promising and well appreciated by administrative authorities in the Delta and could be potentials for improving the planning of economic activities in the Delta. From the interviews conducted among stakeholders, the key conditions for acceptance and use of the diagnostic and planning tools developed for the stakeholders in Inland Niger Delta are (i) capacity building to ensure high confidence in the tool by stakeholders; (ii) continuous funding and technical support for the tool; (iii) mainstreaming of the tool into the programmes of key relevant government agencies involved in the Niger, beyond project-specific supports. 
TABLE OF CONTENTS

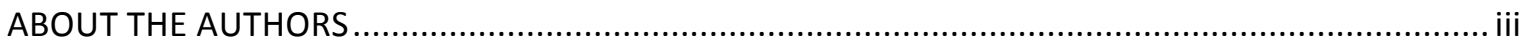

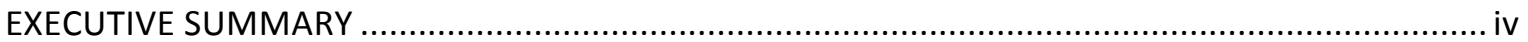

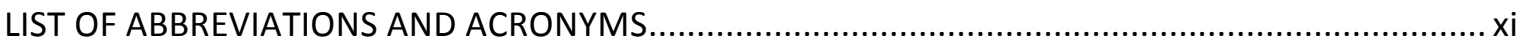

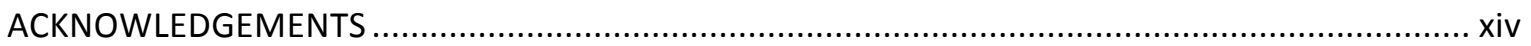

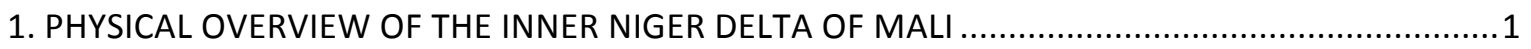

1.1 Location: geographical coordinates and administrative boundaries .......................................1

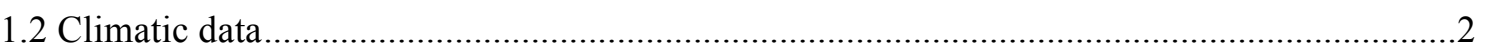

2. DEMOGRAPHIC DATA AND ECONOMIC ACTIVITIES OF THE INLAND NIGER DELTA ................11

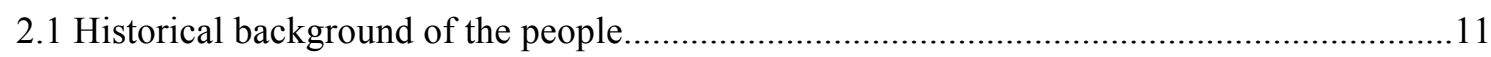

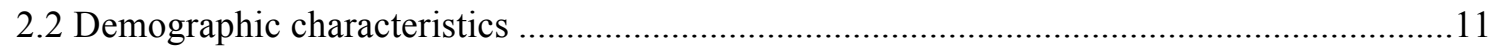

2.3 Social organization, methods of governance and management of local resources ................13

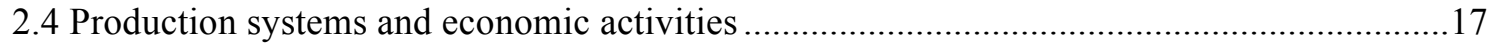

3. POLICIES AND LEGAL SYSTEM OF RESOURCE MANAGEMENT IN THE DELTA ….......................22

3.1 National policies and strategies on natural resource management in the Delta .....................22

3.2 Legal texts and decrees on natural resource management in the Delta ..................................26

3.3 Economic incentives to support environmental management ..............................................28

4. DEVELOPMENT CHALLENGES AND CONSTRAINTS TO NATURAL RESOURCE MANAGEMENT ...30

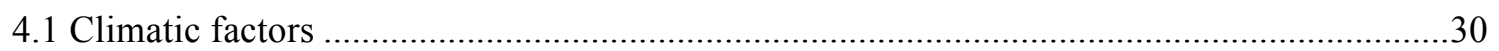

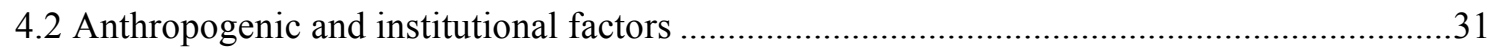

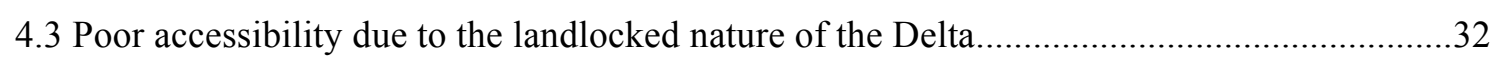

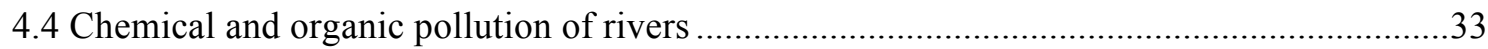

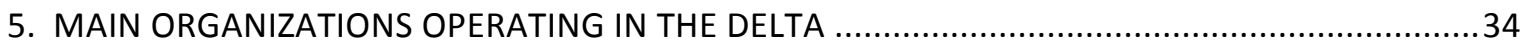

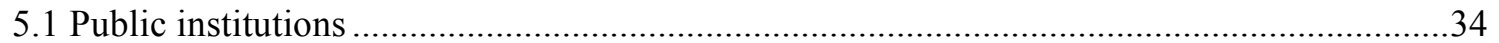

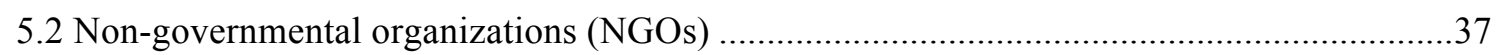

6. DIAGNOSTIC TOOLS AND PLANNING MECHANISMS FOR RESOURCE MANAGEMENT ..............40

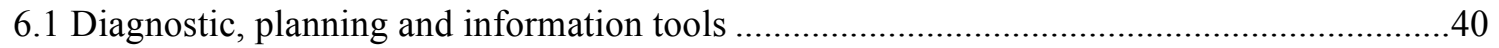

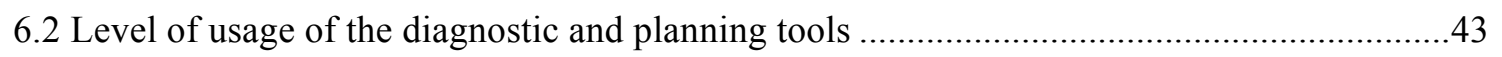

6.3 Planning and resource management mechanisms in the Delta............................................44 
7. SYNTHESIS OF LESSONS LEARNT

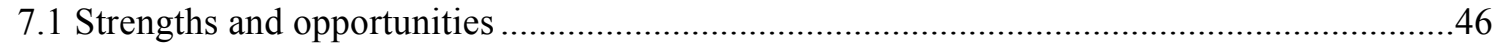

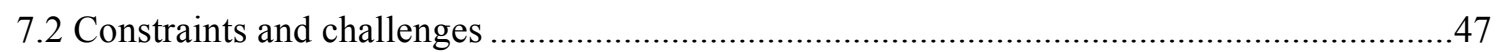

7.3 Approaches to mitigate constraints and challenges ............................................................48

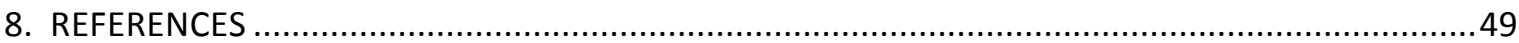




\section{LIST OF ABBREVIATIONS AND ACRONYMS}

\begin{tabular}{|c|c|}
\hline ABFN & Niger River Basin Agency \\
\hline AEDD & Agency for Environment and Sustainable Development \\
\hline AEZ & agro-ecological zones \\
\hline AFAR & Action for Rural Education and self-promotion \\
\hline AFROMAISON & $\begin{array}{l}\text { Africa at Meso-scale: Adaptive and Integrative Tools and Strategies for Natural } \\
\text { Resource Management }\end{array}$ \\
\hline AGRHYMET & $\begin{array}{l}\text { Centre Regional de Formation et d'Application en Agrométéorologie et } \\
\text { Hydrologie Opérationnelle }\end{array}$ \\
\hline ALEF & Forest Office \\
\hline ALP & Local Fisheries Branch \\
\hline AMADER & $\begin{array}{l}\text { Malian Agency for the Development of Domestic Energy and Rural } \\
\text { Electrification }\end{array}$ \\
\hline AOPP & Association of Professional Farmers' Organizations \\
\hline CATI & Conventions, Agreements and International Treaties \\
\hline CCL & Wood Fuel Unit \\
\hline CCSA & Municipal Committee for Food Security \\
\hline CLO & Local Committee for Orientation \\
\hline CLOCSAD & $\begin{array}{l}\text { Local Committee for Orientation, Coordination and Monitoring of Development } \\
\text { Activities }\end{array}$ \\
\hline CLSA & Local Committee for Food Security \\
\hline CPS & Statistics and Planning Unit \\
\hline CRA & Regional Centre for Agricultural Research \\
\hline CRBPO & Centre for Research on Bio-geography of Bird Populations \\
\hline CROCSAD & $\begin{array}{l}\text { Regional Committee for Orientation, Coordination and Monitoring of } \\
\text { Development Activities }\end{array}$ \\
\hline CRS & Catholic Relief Service \\
\hline CSA & Food Security Commission \\
\hline CSCOM & Community Health Centre \\
\hline CSCRP & Strategic Framework for Growth and Poverty Reduction \\
\hline CSLP & Strategic Framework for Poverty Reduction \\
\hline CT & Regional Authority \\
\hline DNCN & National Directorate for Conservation of Nature \\
\hline DNPIA & National Directorate of Animal Production and Industry \\
\hline DNSI & Department of Statistics and Information Science \\
\hline DRA & Regional Directorate of Agriculture \\
\hline DRACPN & Regional Directorate of Sanitation and Control of Pollution and Nuisances \\
\hline DREF & Regional Directorate of Water and Forests \\
\hline DRH & Regional Directorate of Water Resources \\
\hline DRP & Regional Directorate of Fisheries \\
\hline DRPI & Regional Directorate of Production and Animal Industries \\
\hline DRPSIAP & $\begin{array}{l}\text { Regional Directorate of Planning, Statistics and Information Science, Physical } \\
\text { Planning and Population }\end{array}$ \\
\hline ESIA & Environmental and Social Impact Assessment \\
\hline EWS & Early Warning System \\
\hline FODESA & Programme Fonds de développement en zone Sahélienne \\
\hline GDP & Gross Domestic Product \\
\hline
\end{tabular}




\begin{tabular}{|c|c|}
\hline GDRN & Sustainable Management of Natural Resources \\
\hline GIRE & Integrated Management of Water Resources \\
\hline GIZ & Deutsche Gesellschaft für Internationale Zusammenarbeit \\
\hline GRAT & Group for Research and Technology Applications \\
\hline GWP & Global Water Partnership \\
\hline ICRAF & World Agroforestry Centre \\
\hline IEC & Information, Education and Communication \\
\hline IER & Institute of Rural Economy \\
\hline IGN & National Geographic Institute \\
\hline IND & Inner Delta of Niger River \\
\hline IUCN & International Union for Conservation of Nature \\
\hline MEA & Ministry of Environment and Sanitation \\
\hline MEP & Ministry of Livestock and Fisheries \\
\hline NRM & Natural Resource Management \\
\hline $\mathrm{ONC}$ & National Office for Hunting and Conservation of Wildlife \\
\hline OPIDIN & Monitoring and prediction of water level in the Inland Niger Delta \\
\hline PA & Action Plan \\
\hline PADEPECHE & Fisheries Development Support Project \\
\hline PANA & National Action Plan for Climate Change Adaptation \\
\hline PCAE & District Plan for Environmental Action \\
\hline PDD-IND & Sustainable Development Programme of the Inner Niger Delta \\
\hline PDESC & Economic, Social and Cultural Development Plan \\
\hline PEALCD & Environmental Support Programme for the Fight against Desertification \\
\hline PES & Payment for Ecosystem Services \\
\hline PET & Potential Evapotranspiration \\
\hline PNA & National Sanitation Policy \\
\hline PNDE & National Policy on Livestock Development \\
\hline PNE & National Water Policy \\
\hline PNPE & National Policy for the Protection of the Environment \\
\hline PNZH & National Policy on Wetlands \\
\hline POP & Persistent Organic Pollutant \\
\hline PPIV & Small irrigated areas in the village \\
\hline PRODEM & Support Project for Livestock Development in the Region of Mopti \\
\hline PTF & Technical and Financial Partners \\
\hline RGPH & General Population and Housing Census \\
\hline RMT & Rice submersion with total control of water \\
\hline $\mathrm{RSC}$ & Rice in controlled flooding \\
\hline RSL & Rice under open submersion \\
\hline SED & Domestic Energy Strategy \\
\hline SIFOR & Forest Information System \\
\hline SIMES & Multimedia Information System for the sub-Saharan Environment \\
\hline SLEF & Local Department of Water and Forests \\
\hline SLP & Local Department of Fisheries \\
\hline SLPIA & Local Department of Animal Production and Industries \\
\hline SNDI & National Strategy for Development of Irrigation \\
\hline SNSA & National Food Security Strategy \\
\hline UNESCO & United Nations Educational, Scientific and Cultural Organization \\
\hline
\end{tabular}




\section{ACKNOWLEDGEMENTS}

This paper benefited from comments from AFROMAISON project partners who contributed to improving the earlier drafts. In particular, the authors gratefully acknowledge the comments made by Eddy Wymenga, Bakary Koné, Bruno Barbier, Abdoulaye Diarra and Diallo Mori. The Coordinator of AFROMAISON project, Tom D'Haeyer provided overall support to the study team.

We are also grateful to the farmers, fishermen, livestock keepers, policy makers, government officials and NGOs in Mopti who readily responded to our inquiries and made available several documents and that were helpful in the preparation of this paper.

The financial support provided by the European Commission, 7th Framework Programme to the AFROMAISON project, under whose auspices the study was carried out is deeply appreciated.

This working paper does not in any way represent or reflect the official views of the European Commission or its agents. Any errors or omissions contained in the paper are the exclusive responsibility of the authors.

\section{KEY WORDS}

- integrated natural resource management

- watershed

- planning tools

- hydrological assessment

- conflict management 


\section{PHYSICAL OVERVIEW OF THE INNER NIGER DELTA OF MALI}

\subsection{Location: geographical coordinates and administrative boundaries}

The Inner Delta of Niger River, also referred to as the Delta or IND, is located in the central part of Mali and positioned between $17^{\circ} \& 13^{\circ} \mathrm{N}$ and $2^{\circ} 30^{\prime} \& 6^{\circ} 30^{\prime} \mathrm{W}$ (see Figure 1). It is about $350 \mathrm{~km}$ long and $100 \mathrm{~km}$ wide, covering a surface area of $41,195 \mathrm{~km}^{2}$. The area straddles the following administrative areas: Macina cercle in Ségou region; Djenne, Mopti, Tenenkou and Youwarou cercles in Mopti region; Diré, Goundam and Niafunké cercles in Timbuktu region. The Inland Niger Delta is situated between four cercles within a set of 44 administrative districts and 821 villages. Among these cercles, $40 \%$ have less than 25,000 inhabitants and $16 \%$ have more than 25,000 , thus the population density varies from 17 to 21 inhabitants $/ \mathrm{km}^{2}$. Its maximum altitude is $272 \mathrm{~m}$ and the minimum is $262 \mathrm{~m}$ above sea level. The Delta is a complex ecosystem characterized by the existence of three types of natural wetlands, which merge to form one body of water during the rainy season. At the end of the rainy season three aquatic ecosystems clearly appear, namely: the Niger River and its tributary the Bani; lakes and pools and, flood plains.

Figure 1: Position of the Inland Niger Delta within Mali

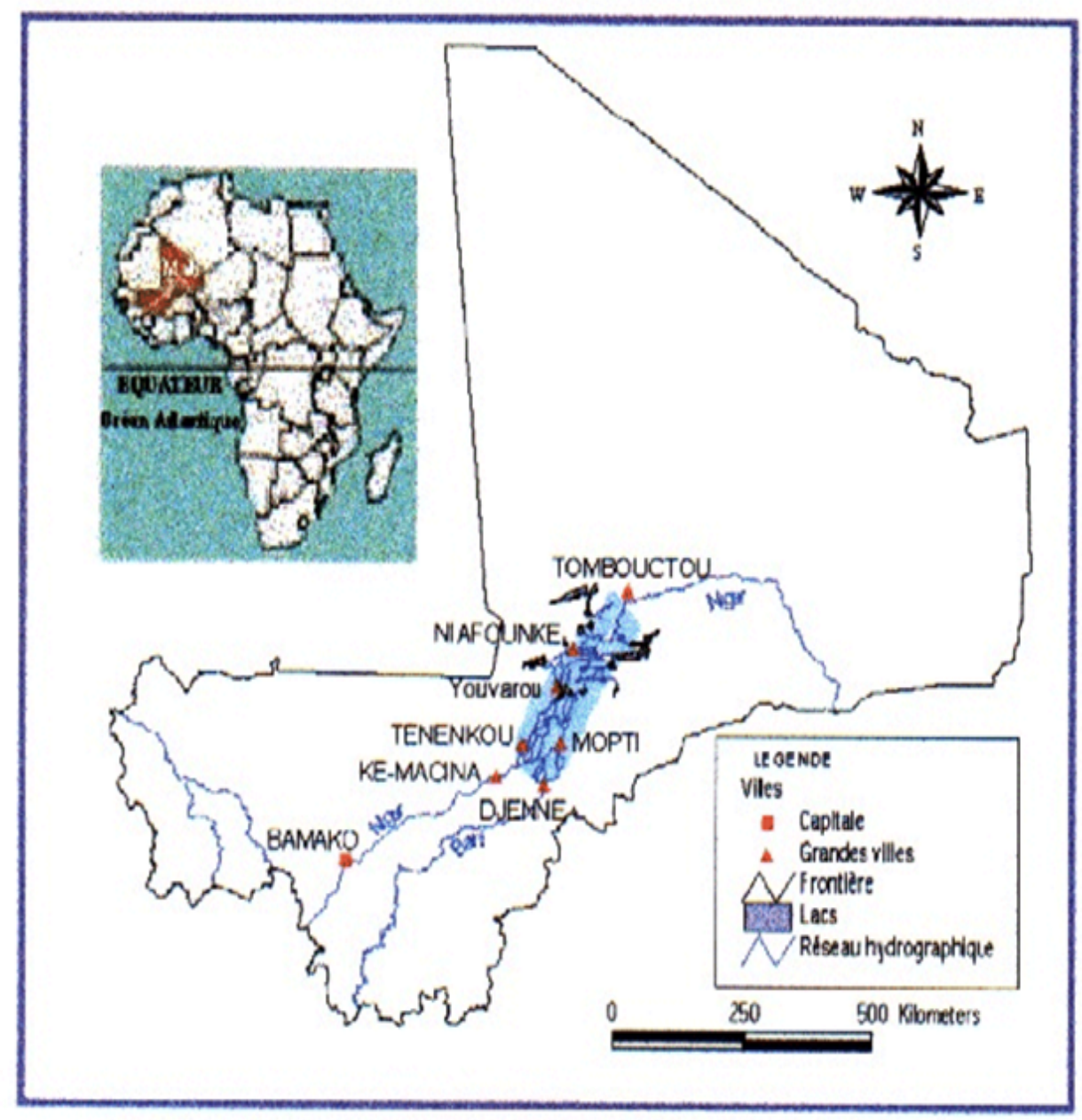




\subsection{Climatic data}

\subsubsection{Agro-ecology and climate}

The Inland Niger Delta is located in the Sahelian zone (see Figure 2) which like the other locations in Mali, alternates between two seasons - a dry season which varies in duration from nine months in the north (October to June) to six months in the south (November to April), and a wet or rainy season from May to October in the south, and from July to September in the north with inter-seasons which are more or less marked. The annual rainfall in the Upper Niger varies from between less than $250 \mathrm{~mm}$ in the north-east to over $1750 \mathrm{~mm}$ in the south-west.

The average temperature ranges between $35^{\circ} \mathrm{C}$ and $45^{\circ} \mathrm{C}$, with an absolute maximum of about $50^{\circ} \mathrm{C}$. Maximum temperatures do not vary a lot throughout the year at any given location; the coefficient of variation was below $10 \%$ in almost all cases. The coefficient of variation of minimum temperature is between $10 \%$ and $23 \%$ during the year. The minimum temperature has a coefficient of monthly variation which is slightly higher than that of the maximum temperature (See Table 2). Average annual rainfall varies from 200 $\mathrm{mm}$ in the north to $600 \mathrm{~mm}$ in the south. The seasons are influenced by two main winds: (i) the harmattan, hot and dry wind blowing from the northeast to southwest, (ii) the monsoon, moist wind and the main vector of rain blowing from the southwest to northeast.

There are several agro-ecological zones (AEZs) in the delta area. According to the ESPR, 1990, there are six AEZs namely:

- Open Delta: this is the largest AEZ in terms of flooded areas. It covers $1500 \mathrm{~km}^{2}$ consisting of $88 \%$ of heavy soils ( $62 \%$ silt clay, $20 \%$ clay loam and $6 \%$ silt). An area of $525 \mathrm{~km}^{2}$ or $4 \%$ of the open delta area is permanently covered by water and represents the fishing areas. Twenty-one percent (21\%) of the AEZ is the grazing area on hydromorphic soils while $75 \%$ is used for both crop cultivation and pasture simultaneously.

- Lake area: this covers an area of $9,900 \mathrm{~km}^{2}$ and is composed of the lake area itself (the whole lake area of Débo, Waladou, Korientzé and their tributaries) and the Farimaké area. Pastures occupy $33 \%$ of the mainly hydromorphic areas while $61 \%$ is cultivated land (of which $15 \%$ is occupied by crop cultivation under floods). The fishing area covers $1,500 \mathrm{~km}^{2}$.

Plateau: in this AEZ, $539 \mathrm{~km}^{2}$ in the southern most part of the plateau is floodprone. The area actually flooded during normal rainfall would be $1 \%$ of the AEZ, which is about $109 \mathrm{~km}^{2}$. 
- Gourma: here the flood areas are mainly located at the level of Lake Korarou and its tributaries, covering some $217 \mathrm{~km}^{2}$. However in case of normal rainfall (at least $30 \mathrm{~mm}$ of rainfall), $185 \mathrm{~km}^{2}$ of land is under water.

- Bodara: this delta space covers some $243 \mathrm{~km}^{2}$ of the AEZ, but the flooded land during normal floods is only $70 \mathrm{~km}^{2}$.

- Mema: in case of normal floods, the flooded area of this zone is $313 \mathrm{~km}^{2}$.

On the other hand, Quensière (1994) divides the Delta into four zones briefly described as follows:

- Upper Delta upstream region of the Delta, also known as Djennéri, extending between Ke-Macina the imaginary line Ténenkou, Kouakourou, Sofara. The area is divided by some large tributaries viz: Niger, Diaka, Bani, SoumanBani and Mayo sogona.

- Mid Delta: located in the southern part of the Central Delta, this part extends between the upper delta and the Togéré-Koumbé line on the Diaka and Konna on the Niger. It contains streams of different capacities (such as Mayo Kotia, Diarendé, Mayo Dembé) and vast flood plains. The latter are home to large areas of bourgou (fodder) fields totaling some $5000 \mathrm{~km}^{2}$.

- Lower Delta: this includes all the Walado Debo lakes, Lake Debo and Lake Korientzé covering a total area of $600 \mathrm{~km}^{2}$ during high floods. It accumulates a large body of water before flowing north through Niafunké. The flooded area is estimated to cover a maximum of $2250 \mathrm{~km}^{2}$, starting from the Korientzé side, north of Bouna, and the Bandiagara Plateau which form the boundary rock of the Delta. The formation of dunes in Niafunké runs along the northern side of the Debo complex and on the eastern side there are two seemingly mountainous rocks: Gouraou and Soroba.

- Northern dune area or Niafunké erg: the northern part of the Delta, often called the lake Delta, stretches from Lake Debo to Timbuktu. It has very different characteristics compared to the sections described above. The Niafunké erg consists of a large area of parallel dune ridges (south-west and east-northeast wind oriented structures). The Niger and two major tributaries, the Bara Issa and the Koli-Koli meander through this landscape of dunes to the north. The spaces between the dunes are filled as per the flood water level. 
The Inner Niger Delta and its surrounding areas can also be divided into 11 agroecological zones or homogeneous geographic entities according to geological, geomorphological, soil, climatic and hydrological features (Mariko, 2003).

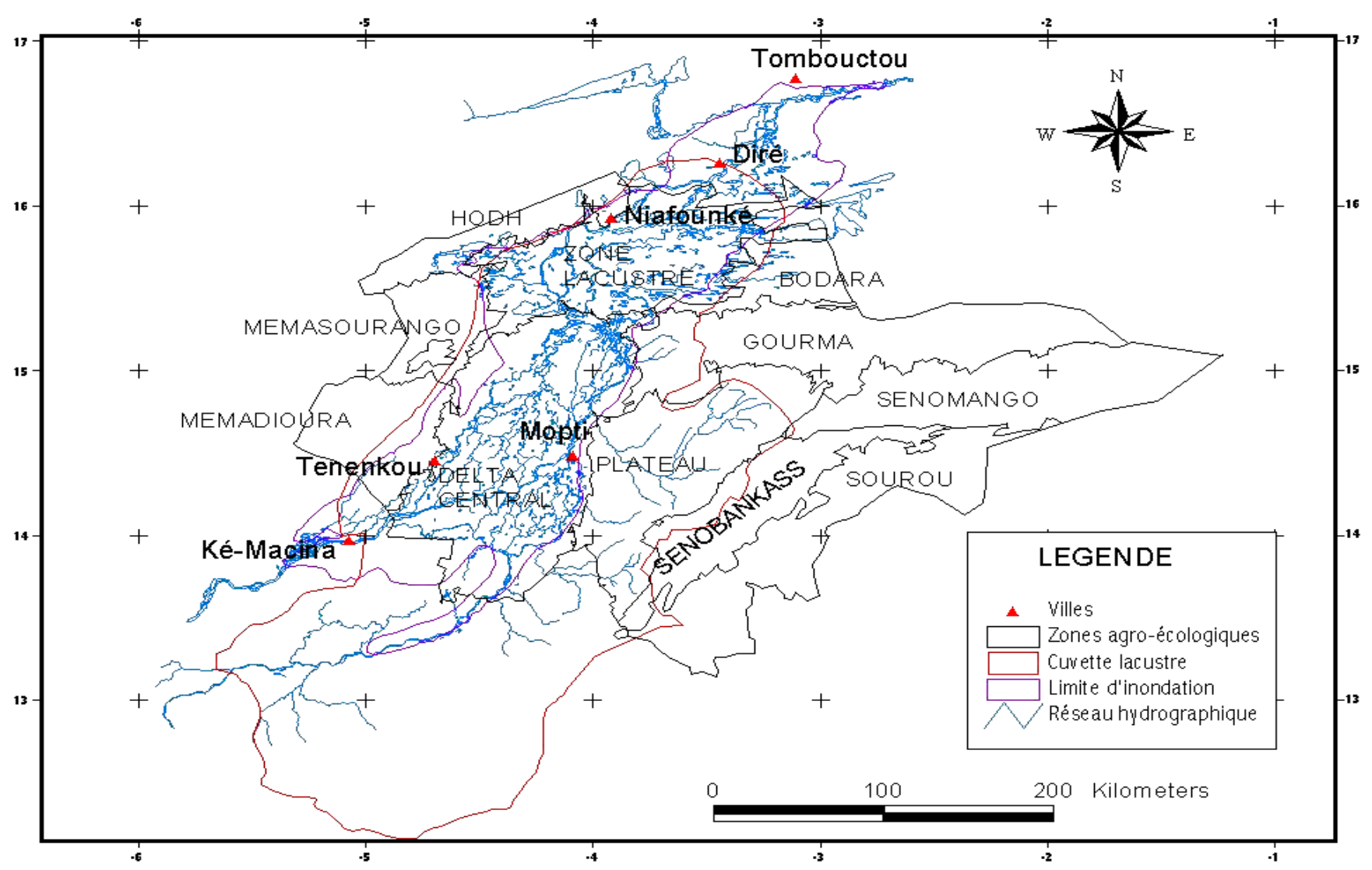

Fig. 2: Geographical boundaries of the agro-ecological zones

Six agro-ecological zones intersect with the catchment area of the delta; from south to north, "the Central Delta", "Plateau", "MémaDioura", "Gourma", "lake area" and "Bodara", covering a total area of nearly $57,000 \mathrm{~km}^{2}$. The agro-ecological zones are divided into taxonomic floodplain units characterized by variables describing flood conditions (water depth, duration of flooding), soil, vegetation, topography and their uses. 
Table 1: Features of taxonomic floodplain units within the Inner Niger Delta extracted from (Dembélé, 1999)

\begin{tabular}{|c|c|c|c|c|c|c|}
\hline $\begin{array}{l}\text { Taxonomic } \\
\text { flood unit }\end{array}$ & Water depth (m) & $\begin{array}{l}\text { Flood } \\
\text { duration } \\
\text { (mths) }\end{array}$ & Soil & Vegetation & Topography & Use \\
\hline T11 & $3-4$ & $6-8$ & Alluvium & $\begin{array}{l}\text { Aquatic weeds } \\
\text { Echinochloa } \\
\text { stagnina Oryza } \\
\text { longistaminata }\end{array}$ & $\begin{array}{l}\text { Flat to } \\
\text { slightly } \\
\text { inclined }\end{array}$ & $\begin{array}{l}\text { Rice } \\
\text { farming } \\
\text { pasture }\end{array}$ \\
\hline $\mathrm{T} 12$ & $1.5-3$ & $3-4$ & $\begin{array}{l}\text { Deep } \\
\text { alluvium }\end{array}$ & rice fields & $\begin{array}{l}\text { Flat to } \\
\text { slightly } \\
\text { inclined }\end{array}$ & $\begin{array}{l}\text { Submerged } \\
\text { rice }\end{array}$ \\
\hline $\mathrm{T} 13$ & 2 & $2-6$ & $\begin{array}{l}\text { Silty } \\
\text { clays }\end{array}$ & $\begin{array}{l}\text { Highly dense } \\
\text { grass } \\
\text { vegetation: } \\
\text { Vetiveria, } \\
\text { Panicum } \\
\text { anabaptistum }\end{array}$ & $\begin{array}{l}\text { Flat to } \\
\text { slightly } \\
\text { inclined }\end{array}$ & $\begin{array}{l}\text { Rice } \\
\text { farming } \\
\text { pasture }\end{array}$ \\
\hline T14 & $0-0.60$ & & $\begin{array}{l}\text { Riverbank } \\
\text { bulge } \\
\text { (loam) }\end{array}$ & $\begin{array}{l}\text { Highly dense } \\
\text { grass } \\
\text { vegetation: } \\
\text { Vetiveria } \\
\text { nigritana }\end{array}$ & $\begin{array}{l}\text { High points } \\
\text { on landscape }\end{array}$ & Pasture \\
\hline T15* & $<1$ & $\begin{array}{l}\text { Temporary } \\
\text { (rain) }\end{array}$ & Clay & $\begin{array}{l}\text { Trees: Acacia } \\
\text { nilotica }\end{array}$ & $\begin{array}{l}\text { Slight } \\
\text { depression }\end{array}$ & $\begin{array}{l}\text { Farming } \\
\text { and } \\
\text { pasture }\end{array}$ \\
\hline T16* & & $\begin{array}{l}\text { Temporary } \\
\text { (rain) }\end{array}$ & $\begin{array}{l}\text { New deep } \\
\text { alluvium }\end{array}$ & $\begin{array}{l}\text { Panicum } \\
\text { laetum, Grasses } \\
\text { (mitragyna } \\
\text { inermis, } \\
\text { vetiveria } \\
\text { nigritana) } \\
\text { aquaphiles, } \\
\text { trees shrubs }\end{array}$ & $\begin{array}{l}\text { Flat- } \\
\text { bottomed } \\
\text { valley }\end{array}$ & $\begin{array}{l}\text { Rice } \\
\text { farming } \\
\text { pasture }\end{array}$ \\
\hline T17 & & $\begin{array}{l}\text { Deep } \\
\text { alluvium }\end{array}$ & & $\begin{array}{l}\text { Herbaceous } \\
\text { vegetation } \\
\text { (wetlands) }\end{array}$ & Lake shores & $\begin{array}{l}\text { Receding } \\
\text { water } \\
\text { cultivation }\end{array}$ \\
\hline $\mathrm{X} 6$ & Permanent & $\begin{array}{l}\text { Lake } \\
\text { Débo... }\end{array}$ & & & & $\begin{array}{l}\text { Fishing } \\
\text { and } \\
\text { transport }\end{array}$ \\
\hline
\end{tabular}

* Units T15 and T16 are not linked to the delta system

The vegetation is directly influenced by the changes in climate and flooding along the Delta, and consists of Sahelian and Soudano-Sahelian species, Acacia and Combretaceae. This is the area of extensive pastoralism and transhumance. The Delta also contains flood forests of Acacia kiirki, which offer refuge to hippos and manatees and are resting and breeding places for hundreds of thousands of palearctic and afro-tropical birds (IUCN, 2002).

\subsubsection{Hydrography and hydrology}

The Inland Niger Delta is a vast seasonal floodplain which is influenced by the River Niger (see Figure 3). The floods rise between June and November and then recede until 
April or May. The hydrology is critical to the functioning of the delta ecosystem and the success of the economic activities. It is characterized by large intra-annual variations, and large inter-annual variations: low water levels from March to May, floods from June to October, and receding waters from November to February. The main factors influencing the flow of the Niger River and flooding of the plains are: (i) rainfall, especially from the rainfall on the mountains of Guinea that may reach up to $2500 \mathrm{~mm}$ per year or more. The higher the rain upstream, the more the flow into the Delta and the more the plains are filled, (ii) slope, mild with low gradients; (iii) Fomi dams in Guinea which are not yet operational and Sélingué, Markala, Talo dams which are all functional and located in Mali; (iv) withdrawal of water for irrigation purposes; (v) water recharges from groundwater; (vi) siltation. The lakes found in the region include: Korientzé and Débo in the central part, Niangaye, Do, Haribomo and Aoungoudou on the right bank, Kabara, Tanda, Fati, Horo, Télé and Faguibine on the left. Every year simultaneous floods from two large rivers cover the vast surfaces of this huge delta and the water level increases depending on the intensity of floods from 4.5 to $7 \mathrm{~m}$ above the low water levels. It is estimated that the annual maximum flooded areas vary from between $35,000 \mathrm{~km}^{2}$ during a wet year to $7,000 \mathrm{~km}^{2}$ during a dry year.

\subsubsection{Flooding}

Flooding is attributed to the height of the water level (flood) and the volume of rainfall upstream of the Delta in Guinea and Côte d'Ivoire. The actual contribution of rainwater in the zone itself to the flooding phenomenon in the Delta is relatively small. Its parameters are frequency, duration, height, date (earliness or lateness of flooding and drop in water levels) and the speed of receding water (see Figure 3). Floods may be classified as low, medium or high depending on the level of water. Thus, a flood is regarded as normal if it is $660 \mathrm{~cm}$ in Mopti, high if it is above $660 \mathrm{~cm}$ and low if the level is less than $660 \mathrm{~cm}$. An exceptionally high flood occurred in 1924 with a height of $741 \mathrm{~cm}$ and the lowest flood occurred in 1984 measuring $440 \mathrm{~cm}$. At a height of $660 \mathrm{~cm}$, almost all the flood prone areas of the Delta are under water; at $510 \mathrm{~cm}$, the majority of the basin is no longer flooded, and the areas under water are only the deep basins (J. Marie, 2002, DELMASIG). Besides the River Niger, the Bani River also feeds the area. A number of factors cause the discharge levels of Upper Niger River to vary significantly. These include climate, groundwater, seasonal variation, the construction of dams and reservoirs. The three main dams that are functioning upstream Inner Niger Delta and which affect water flow entering the Delta are Selingué, Markala and Talo Dams (the latter is on the tributary of River Niger). 


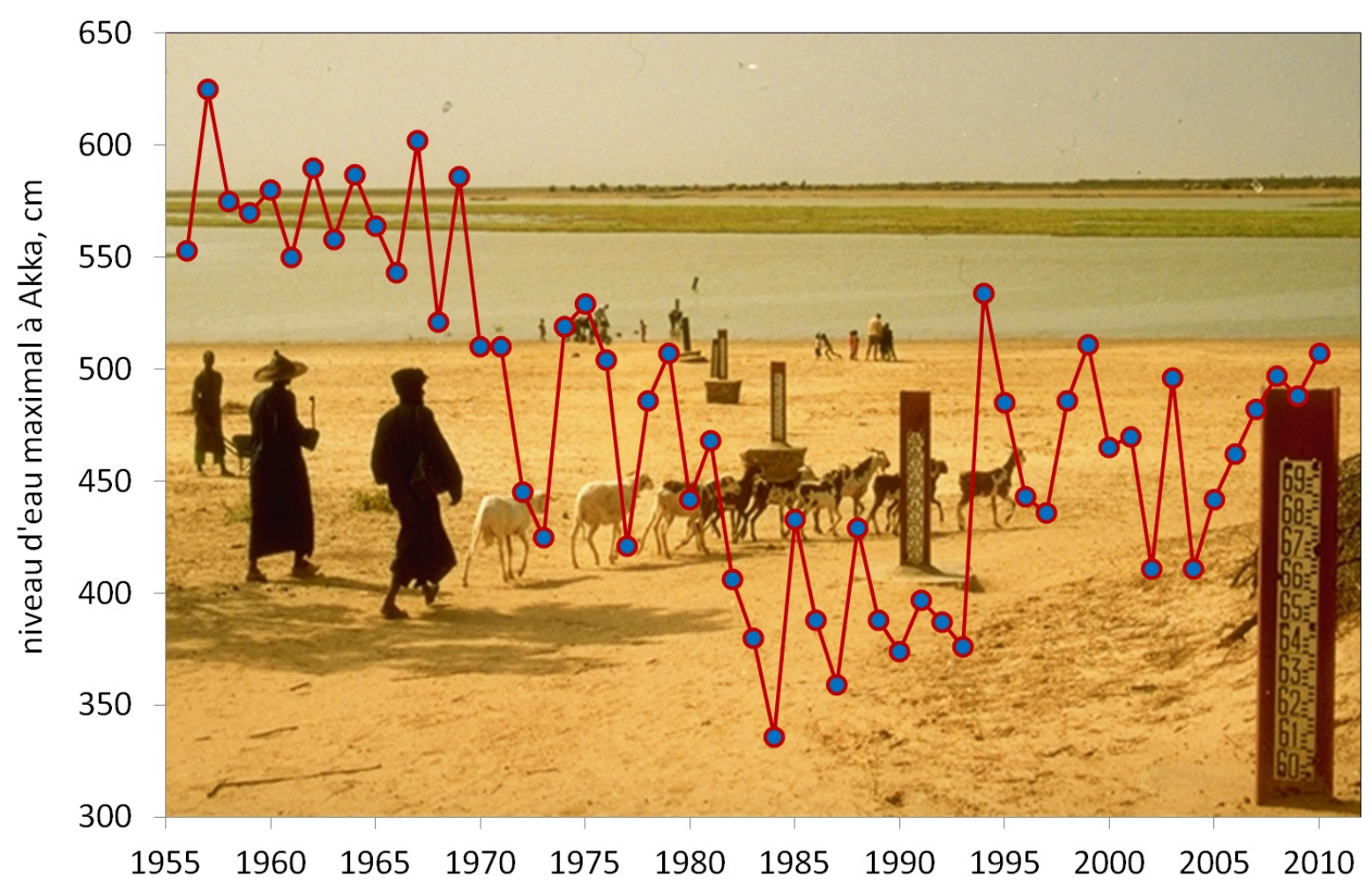

Figure 3: Water level at the gauge of Akka from 1955 to 2010. Data DNH. From Zwarts et al. 2005, Wetlands International / A\&W.

The speed of the floods varies according to the water volume (upstream rainfall) and the slope level which determines the strength of flow. Between Kemacina and Dire (4,560 km, Delta area) the slope is $3 \mathrm{~cm} / \mathrm{km}$ compared to $20 \mathrm{~cm} / \mathrm{km}$ from the border with Guinea and Kémacina, and $4 \mathrm{~cm} / \mathrm{km}$ between Koulikoro and Kemacina (Source DRHE Mopti 2002). Dams, banks and other obstacles also affect the timing and duration of the floods which in turn determine the level of flooding. During an early flood, the maximum height $(6.60 \mathrm{~m})$ is reached in October in Mopti. Five weeks is enough for water to cover the Delta if the recession does not start immediately. With a late flood, the maximum level is reached in Mopti in mid-November and it takes seven weeks for the wave of flooding to reach Dire in mid-January. All dams and other banks delay the rise of the flood water level (depending on its strength) and at the same time cause early recession of waters; both cases negatively affect the flooding of the Delta. Given that the decline in average inter-annual rainfall is between $30 \%$ to $94 \%$ from 1950 to 2003 , almost half of the flood plains in the Delta are no longer flooded today. 
Table 2: Seasonal variation of floods as recorded at Mopti station (maximum height in $\mathrm{cm}$ ) from 1945 to 2004

\begin{tabular}{|c|c|c|}
\hline Year & Date & $\begin{array}{c}\text { Maximum } \\
\text { height }\end{array}$ \\
\hline $\mathbf{1 9 4 5}$ & $06-11$ & 693 \\
\hline $\mathbf{1 9 4 6}$ & $01-11$ & 700 \\
\hline $\mathbf{1 9 4 7}$ & $25-10$ & 653 \\
\hline $\mathbf{1 9 4 8}$ & $19-10$ & 654 \\
\hline $\mathbf{1 9 4 9}$ & $19-10$ & 650 \\
\hline $\mathbf{1 9 5 0}$ & $10-11$ & 707 \\
\hline $\mathbf{1 9 5 1}$ & $03-12$ & 712 \\
\hline $\mathbf{1 9 5 2}$ & $18-11$ & 719 \\
\hline $\mathbf{1 9 5 3}$ & $31-10$ & 731 \\
\hline $\mathbf{1 9 5 4}$ & $04-11$ & 731 \\
\hline $\mathbf{1 9 5 5}$ & $06-11$ & 731 \\
\hline $\mathbf{1 9 5 6}$ & $29-10$ & 686 \\
\hline $\mathbf{1 9 5 7}$ & $17-11$ & 730 \\
\hline $\mathbf{1 9 5 8}$ & $01-11$ & 707 \\
\hline $\mathbf{1 9 5 9}$ & $31-11$ & 691 \\
\hline $\mathbf{1 9 6 0}$ & $01-11$ & 691 \\
\hline $\mathbf{1 9 6 1}$ & $01-11$ & 694 \\
\hline $\mathbf{1 9 6 2}$ & $04-11$ & 702 \\
\hline $\mathbf{1 9 6 3}$ & $16-11$ & 680 \\
\hline $\mathbf{1 9 6 4}$ & $03-11$ & 717 \\
\hline
\end{tabular}

\begin{tabular}{|c|c|c|}
\hline Year & Date & $\begin{array}{c}\text { Maximum } \\
\text { height }\end{array}$ \\
\hline $\mathbf{1 9 6 5}$ & $01-11$ & 684 \\
\hline $\mathbf{1 9 6 6}$ & $09-11$ & 686 \\
\hline $\mathbf{1 9 6 7}$ & $11-11$ & 720 \\
\hline $\mathbf{1 9 6 8}$ & $25-10$ & 651 \\
\hline $\mathbf{1 9 6 9}$ & $01-11$ & 684 \\
\hline $\mathbf{1 9 7 0}$ & $22-10$ & 666 \\
\hline $\mathbf{1 9 7 1}$ & $20-10$ & 651 \\
\hline $\mathbf{1 9 7 2}$ & $07-10$ & 565 \\
\hline $\mathbf{1 9 7 3}$ & $03-10$ & 568 \\
\hline $\mathbf{1 9 7 4}$ & $18-10$ & 650 \\
\hline $\mathbf{1 9 7 5}$ & $26-10$ & 663 \\
\hline $\mathbf{1 9 7 6}$ & $21-11$ & 623 \\
\hline $\mathbf{1 9 7 7}$ & $10-10$ & 566 \\
\hline $\mathbf{1 9 7 8}$ & $22-10$ & 520 \\
\hline $\mathbf{1 9 7 9}$ & $06-10$ & 638 \\
\hline $\mathbf{1 9 8 0}$ & $07-10$ & 592 \\
\hline $\mathbf{1 9 8 1}$ & $14-10$ & 628 \\
\hline $\mathbf{1 9 8 2}$ & $29-09$ & 551 \\
\hline $\mathbf{1 9 8 3}$ & $14-10$ & 507 \\
\hline $\mathbf{1 9 8 4}$ & $19-10$ & 440 \\
\hline
\end{tabular}

\begin{tabular}{|c|c|c|}
\hline Year & Date & $\begin{array}{c}\text { Maximum } \\
\text { height }\end{array}$ \\
\hline $\mathbf{1 9 8 5}$ & $13-10$ & 571 \\
\hline $\mathbf{1 9 8 6}$ & $08-10$ & 534 \\
\hline $\mathbf{1 9 8 7}$ & $17-10$ & 481 \\
\hline $\mathbf{1 9 8 8}$ & $08-10$ & 571 \\
\hline $\mathbf{1 9 8 9}$ & $05-10$ & 517 \\
\hline $\mathbf{1 9 9 0}$ & $09-10$ & 510 \\
\hline $\mathbf{1 9 9 1}$ & $05-10$ & 530 \\
\hline $\mathbf{1 9 9 2}$ & $07-10$ & 538 \\
\hline $\mathbf{1 9 9 3}$ & $06-10$ & 498 \\
\hline $\mathbf{1 9 9 4}$ & $28-10$ & 655 \\
\hline $\mathbf{1 9 9 5}$ & $25-10$ & 614 \\
\hline $\mathbf{1 9 9 6}$ & $17-10$ & 595 \\
\hline $\mathbf{1 9 9 7}$ & $13-10$ & 580 \\
\hline $\mathbf{1 9 9 8}$ & $25-10$ & 639 \\
\hline $\mathbf{1 9 9 9}$ & $24-10$ & 662 \\
\hline $\mathbf{2 0 0 0}$ & $23-10$ & 608 \\
\hline $\mathbf{2 0 0 1}$ & $19-10$ & 621 \\
\hline $\mathbf{2 0 0 2}$ & $08-10$ & 438 \\
\hline $\mathbf{2 0 0 3}$ & $15-10$ & 649 \\
\hline $\mathbf{2 0 0 4}$ & $18-10$ & 561 \\
\hline
\end{tabular}

\subsubsection{Ecological and biological importance}

The delta ecosystem is the largest reservoir of biological diversity in Mali and in Africa in general. For this reason, it was classified by UNESCO in February 2004 as a Ramsar World Heritage site for humanity ${ }^{1}$. It is a "biotic production machine" because of the diversity of aquatic environments (natural water bodies, basins, and currents), strong seasonality of low water levels and floods, and the variety of land use systems, which are a source of enrichment. In terms of size, the Inland Niger Delta is the largest and most populous of inland wetlands in West Africa covering about $15,000 \mathrm{~km}^{2}$ in flood zones and $13,000 \mathrm{~km}^{2}$ in peripheral areas. In Africa, it ranks second only to the Okavango Delta in Botswana.

\footnotetext{
${ }^{1}$ The IND meets criteria 1,2, 3, 4, 5, 6 and 7 of the Ramsar Convention: Information Sheet on Ramsar Wetlands (FDR) DNCN

2 The most important are Kaniana, Tonomba and Djenné-Djenno, discovered by American archaeologists, Mr. and Mrs. Mac Intosch in
} 
Since the period of Dina, the flora in the Inland Niger Delta has been sufficiently exploited by rural communities. A large part of this flora composed of several species of palm (Borassus aethiopiu, Hyphaenathebaica), Andropogon gayanus, Vetiveria nigritiana, Echinochloa stagnina and Echinochloa pyramidalis, Acacia albida and several Combretum (Combretum spp) have been intensively exploited and are now considered vulnerable and endangered in the Delta. Drought and the strong anthropic pressure (felling of certain species of trees for construction) have led to the total degradation of the ecological sites that are home to these species. Before the years of drought the wildlife potential of the Inland Niger Delta was rich. The sites of Kémacina (Fallah de Molodo), Akka-Goun (Youvarou cercle) Barikondaga opposite the governorate in Mopti are known as ecological areas of choice and threatened or endangered species. As for mammals, Hippopotamus amphibius (Hippo) and Trichechus senegalensis (manatees) species on the IUCN red list still exist, but they are endangered in the Delta, in particular the manatee. Among the rare and unusual species found in the Delta are the python (Python spp) and monitor lizards (Varanus Spp), marabou (Leptoptilos spp), crowned crane (Balearica pavonina), spatula (Platalea alba), ibis (Threskiornis aethiopica). These flora and fauna resources contribute immensely year after year to the basic needs and the socio-economic and cultural development of the communities. The ecology of the Inner Niger Delta is described in detail by amongst others Zwarts et al. 2009 (Living on the Edge) and Marie et al. 2009 (Avenir du Niger).

Regarding bird life, the Inland Niger Delta plays a key ecological function (breeding, feeding dormitory) and it is one of the richest wetlands of West Africa. More than 100,000 birds of 15 different species use the flooded forest of the Delta as their breeding site. In term of water birds, 30 species have fulfilled the $1 \%$ criteria of the Ramsar Convention and more than $50 \%$ of the Caspian Tern population from Europe use the Delta as a wintering ground. It is the largest wintering area of West Africa which hosts thousands of birds annually from Eurasia and Afro-tropical species. Studies by the Centre for Research on Bio-geography of Bird Populations (CRBPO) and National Office for Hunting and Conservation of Wildlife (ONC) confirmed the evolution of Anatidae populations in the Inner Niger Delta. During the last inventory done by Wetlands International/Sévaré (Ecology and sustainable management of natural resources: Inner Niger Delta 1998-2002) the maximum results for the period 1998 to 2001 during the monthly censuses indicate the presence of several species considered vulnerable, threatened and/or rare in the Inner Niger Delta. These species are: Egrettaardesiaca $(1,000)$, Threskiornis aethiopica $(3,300)$, Platelea alba (1,000), Alopochen aegyptiacus (180), Nettapus auritus (100), Porphyrio porphyrio (1,000), Glareolacinera (100), Gallinago media (350), Sterna albifrons (340). In addition to these main activities, exploitation of water birds is a very common activity especially when water levels are low during the dry season. In 1999, an estimated 62,500 water birds were sold for about CFA 18 million. 
The Inland Niger Delta is a spawning ground for several fish species identified in the basins of Niger, Senegal and Congo. In 1954, DAGET identified approximately 138 species of 58 genera belonging to 26 families. The main species and subspecies of fish in the Delta belong to the genera Alestes, Synodontis, Hydrocyon, Tilapia, Labeo, Bagrus, Mormyrus and Citharinus. The species are endemic and belong to the class of Osteichtyons, i.e., fish with bony skeleton. More than 70 species are regularly found in the catches. However, 17 species are the most important and in 1991 accounted for over 85\% of the total catch in the Delta (Quinsière et al 1994). The latter belong to the following six families: Cichlidae, Claridae, Charicidae, Baggridae, Cypunidae and Centropomidae.

Almost all economic activities (agriculture, livestock farming, fishing, gathering, river transport, and energy production) revolve around these resources. The lakes, floodplains and swamps listed above are highly productive natural habitats and food sources that have been playing an important role in the socio-economic and cultural development of the riparian communities. However, most of the biological resources have dwindled in number due to poaching and degradation of their habitat. They are now classified as vulnerable or endangered species.

\subsubsection{Biogeography}

The Inland Niger Delta is a fluvial and lake environment which occupies a large area of Mali. The vegetation of the Delta is variable and in its forests we find dense thorny thickets of Acacia seyal and Acacia ataxancantha. The expansive natural environment of the Delta can be described as follows:

- Permanent open water area formed by the river at low water levels

- Open water area which is periodically flooded

- Area periodically flooded at quite significant depth

- Area periodically flooded at shallow depth

- Wooded area which is very often flooded

- Islets referred to as toggéré.

The fodder bank consisting of Echinochloa stagnina covers the areas periodically flooded between the depths of $-150 \mathrm{~cm}$ to $70 \mathrm{~cm}$. Above $70 \mathrm{~cm}$, the vegetation depends on soil type. Areas covered by silt and clay soils are occupied by thorny thickets, especially Acacia ataxacantha and Pterocarpus lucens. Alluvial soils are occupied by Vetiveria nigritiana. In the Delta, the relief is alluvial classical type. The condition of the soils are linked to their morphological, texture and hydromorphic characteristics. From the highland to lowlands, soils of various types can be found including those with raw minerals, muddy soils that become very hard during the dry season (ferruginous soils), soils with clay and lime, soils with clay and black colour (vertisoils). 


\section{DEMOGRAPHIC DATA AND ECONOMIC ACTIVITIES OF THE INLAND NIGER DELTA}

\subsection{Historical background of the people}

The Inland Niger Delta is the bridge of the nomadic and the sedentary world between the Maghreb and Black Africa. Research indicates that the Inland Niger Delta could have been occupied from periods before the Birth of Christ as evidenced by the numerous $\operatorname{archaeological~sites~}^{2}$ (65 listed) within a radius of $5 \mathrm{~km}$ around the present day town of Djenné, an intersection point used during the trans-Saharan trade.

The Inland Niger Delta is not the exclusive domain of one ethnic group even if "ethnic pockets" can be noticed there because of the history of the area. The basic unit of settlement is the village (grouped and permanent settlements) which comprise livestock keepers, farmers and fishermen. Until the advent of colonization, this village organization was based on a pastoral territorial organization, the Leydi, managed by the Jowro under the authority of a political power (the chief of the Dina). The predominant pattern of the village organization (pastoral and fishing) arises from the type of settlement instituted by the Fulani and Bozo fishermen, their economic power and the strengthening of political responsibilities acquired throughout history. Presently, the introduction of the process of decentralization has significantly empowered these village organizations that are officially recognized, unlike organizations in pastoral and fishing territories which do not have de jure recognition.

\subsection{Demographic characteristics}

\subsubsection{Population}

IND comprises 43 municipalities among which $40 \%$ have less than 25,000 inhabitants and $16 \%$ have over 25,000 inhabitants. The biggest municipalities are located on the western part of the Delta. The characterization of the population was made on the basis of the results of the General Population and Housing Census (RGPH) conducted in 2009 by the National Institute of Statistics (INS). The population of the four cercles was 927,345 people $^{3}$ of which about $51 \%$ are women. The population density in the Delta varies between 17 and 21 inhabitants $/ \mathrm{km}^{2}$. It is composed primarily of the Bambaras who are mainly farmers, the Fulanis who are mainly pastoralists and agro-pastoralists, the Sonrhaïs who are agro-fishermen and agro-pastoralists, the Bozos who are fishermen, and the Tamasheqs who are mainly livestock keepers. From 1998 to 2007, the population increased by about $40 \%$, with a predominantly relatively young population where over

\footnotetext{
2 The most important are Kaniana, Tonomba and Djenné-Djenno, discovered by American archaeologists, Mr. and Mrs. Mac Intosch in 1980 .

${ }^{3}$ General Housing and Population Census, DNSI 2009
} 
half $(54 \%)$ of the population is less than 15 years old. The average annual growth rate of the Delta was $1.3 \%$ which is a relatively low rate compared to the national average which stands at $1.8 \%$.

Table 3: Population and growth rate in the Delta between 1996 and 2007

\begin{tabular}{|l|c|c|c|}
\hline \multirow{2}{*}{\multicolumn{1}{c|}{ Cercles }} & \multicolumn{2}{|c|}{ Population } & $\begin{array}{c}\text { Growth Rate } \\
\mathbf{\%}\end{array}$ \\
\cline { 2 - 3 } & $\mathbf{1 9 9 6}$ & $\mathbf{2 0 0 7}$ & 6,39 \\
\hline Mopti & 311.621 & 332.915 & 27,16 \\
\hline Bandiagara & 209.264 & 287.294 & 33,71 \\
\hline Bankass & 163.653 & 246.900 & 29,19 \\
\hline Djenné & 138.224 & 195.221 & 16,91 \\
\hline Douentza & 164.080 & 196.718 & 26,53 \\
\hline Koro & 248.161 & 337.787 & 6,49 \\
\hline Tenenkou & 150.191 & 160.622 & 33,60 \\
\hline Youvarou & 71.595 & 107.840 & $\mathbf{2 2 , 4 9}$ \\
\hline \multicolumn{2}{|c|}{} \\
\hline
\end{tabular}

Source: Estimation DRPSIAP-M base DNSI (RGPH avril 1998 et Perspective)

\subsubsection{Immigration to and emigration from the Delta}

According to the $2007^{4}$ estimates, $77 \%$ of the population in the Delta is rural. Due to uncertainty and unstable climatic conditions which often lead to crop failures, the Delta experiences high migration within the country to destinations such as Sikasso, Segou and Bamako. At an international level, people in the Delta often migrate to Ivory Coast, Burkina Faso, Senegal and Niger. The unemployment rates range from 30\% to 50\% in the $\mathrm{IND}^{5}$ with a very pronounced trend in the cercles of Tenenkou and Youwarou where the rural migration is very high.

Migration is a strategy to limit or mitigate the effects and consequences of drought to the family economies especially during periods of poor harvests. Emigrants secure temporary employment where they can generate cash income to meet certain needs (purchase food and medicines, pay taxes, etc). However, despite the financial benefits it generates, it has negative effects on the economic, social and cultural development of the region.

According to the report of the DNSI (General Population and Housing Census, 2009), the average rate of food insecurity was $56.4 \%$ with a very pronounced trend in the cercles of Djenne and Youwarou (100\% and 55\% respectively).

\subsubsection{Access to basic social services}

Health services: The state of health services in the Delta is very precarious and is exacerbated by its isolation. Due to the permanent presence of surface water (swamps,

\footnotetext{
${ }^{4}$ Report of Regional Diagnosis, 2007

${ }^{5}$ Cf Draft Regional Master Plan for Vocational and Technical Training and Employment, Mopti Regional Assembly, 2011
} 
lakes and channels) and high humidity, it is a potential area for easy transmission of parasitic diseases, especially malaria. For a population of about one million inhabitants, the Delta has only one regional hospital and 27 community health centres (CSCOM) serving 44 municipalities and 821 villages. The ratio currently stands at one doctor for 62,624 inhabitants.

Education: Due to the continued influence of the Dina system, the rate of enrollment of children in schools in the Delta is low to medium, with a lower rate among the girls compared to the boys.

Access to potable water: According to the figures published by the DRH 2007, out of 821 villages on the Delta, 672 villages $(82 \%)$ has at least a functional potable water source (pump or fountain). There are some disparities in the level of water quality in the different villages.

Table 4: School enrolment rate in the Delta

\begin{tabular}{|l|l|l|l|}
\hline School year & $\begin{array}{l}\text { School-age population } \\
\text { (7-12 years) }\end{array}$ & School population & Gross enrollment rate \\
\hline $2004-2005$ & 296,577 & 151,156 & 50.97 \\
\hline $2005-2006$ & 304,631 & 139,999 & 45.96 \\
\hline $2006-2007$ & 312,885 & 148,941 & 47.60 \\
\hline $2007-2008$ & 321,357 & 157,548 & 49.03 \\
\hline
\end{tabular}

Source: DRPSIAP - M and Mopti Academies

\subsection{Social organization, methods of governance and management of local resources}

\subsubsection{Traditional institutions for managing natural resources in the Delta}

Access and control of strategic resources (land, pasture and water) in the Delta is still influenced by the Dina which began under the theocratic empire of Macina ${ }^{6}$. Human activities are organized and operated according to the climatic seasons and as determined locally by the rhythm of flooding and by the abundance or shortage of water. The use of resources in the Inland Niger Delta follows a method of alternating management. When the river is under low floods, the banks are primarily the domain of the Fulani who find fresh grass for the animals and when the river swells, the livestock keepers make way for farmers to sow local rice. In the same space, fishing takes place during alternate periods. Local rules were therefore established by the farmers, herders and fishermen to equitably share the resources. Consequently, local traditional institutions were established to manage the resources. In the Delta, local institutions involved in resource management

\footnotetext{
${ }^{6}$ From 1810 to 1862 under Seekou Amadou, King of the Empire of Macina
} 
of land, pasture and fishing bodies are numerous but mutually reinforcing. The management mechanisms for the resources in the Delta include the following:

\section{The 'ji-tu' or 'ji-tigi'}

Also known as the 'masters of water', these groups usually belong to the Bozo ethnic group, and are chosen by the family council comprising heads of families of the same lineage. The council is generally headed by the oldest member who administers the fisheries on behalf of the community. The 'masters of water' have internal organization mechanisms for monitoring water and fishing activities in the camps. This organization relies on young people referred to as 'delegates' who conduct tours of the camps and the prohibited zones and intervene in the resolution of current problems. They are paid by the 'master of water' from the revenues earned from collective fisheries. Some reports indicate that certain families had a more influential position compared to others on the management of a body of water, which suggests an organization based on the rule of law. The number of 'masters of water' in the IND cannot be accurately determined. According to the Local Department of Regulation and Control of Youwarou, 25 official managers were identified in the cercle in 2004, a figure well below reality. Given the numerous branches of the river, lakes and swamps, the technical services, elected officials, fishermen and 'masters of water' interviewed are unanimous that there are hundreds of 'masters of water' across the delta.

The water institutions were based on the specialization of the different actors, level of knowledge of the resources and their ecology, diversification of the modes and areas of fishing, and the almost divine power of the 'masters of water' hence a strict compliance by the believers of rules and ethics. Knowledge of the environment and population dynamics of fish allowed the fishermen to optimally exploit the resources. The low catch capacity of the fishing gear and given that fishing was mainly for domestic consumption allowed the resources to regenerate. It should be added that the demand for resources was low and alternative sources of products for consumption were abundant.

However, the rules for clan and/or family management were discriminatory, as they gave the first priority to the family of the 'master of water', then the resident families and thereafter the foreigners. Respect for precedence which remains the foundation of these institutions almost permanently favoured founding families. In addition, these institutions only focused on resource use and no action was taken to promote resource development. The intervention of the State and the negative influence of money on the daily lives of the fishermen has corrupted the system and the result has been overexploitation of resources.

\section{The 'Diowro'}

They are also known as 'masters of land and pastures'. Historically, there is a de facto established division of the natural resources of the Delta among the communities: the high 
plains and borders of the flood zone belong to farming communities, rivers and their branches, lakes and swamps belong to fishermen and grass on receding water basins are assigned to pastoralists. However, the increasing number of nomadic pastoralists, the richness and seasonality of pasture and political rivalries between Fulani clans and lineages resulted in a form of ownership and control of access to fodder banks by lineages or groups of families (Suudu baaba). In respect of precedence of occupation, family and political alliance, demographic and military power, and progressive breakdown of institutions managing the Delta, different groups of lineage were established under the management of the nomadic camp leaders (Diom Ouro).

As the manager of pastures and herdsmen, the Diowro's main mission was to implement the annual pastoral schedule drawn up each year by a conference of political and military leaders of the provinces. On the ground he had to enforce the calender of entry of herds in the pastures of leydi, supervise the succession of herds in their movement, control the number of foreign herds in pastures, collect the fee (tolo). The amount paid was capped and distribute through the bessema. With time the power of the Diowro grew and they became the masters of the bourgou family and received ever increasing royalties charged on foreign herds in the absence of any regulatory policy and family control.

After independence, in accordance with the ideological choices of socialism, the new regime proclaimed the 'nationalization' of grazing land and waters and declared by decree that the tolo, the traditional pecking order and the position of the Diowro were illegal. A short period of crisis followed at the level of local institutions marked by increased conflict among pastoralist groups in the grazing fields. The annual local and regional conferences on fodder banks brought together political and administrative authorities and representatives of various economic and technical services of the district with the aim of setting the dates of the different crossings of rivers and marshlands, and entry into the main fodder banks. They recorded the grievances of the farmers and took security measures when peace seemed threatened among groups of pastoralists.

Conflicts among herders of the same lineage were increasing on matters related to access to pasture, seniority, the demarcations of fodder banks, the succession of the Diowro, collection and distribution of goods received from royalties, non-compliance on free pasture zones and the increasing free zones being taken up for fee collection. Following these multiple conflicts, new decision-making authorities (Diowro and Sub-Diowro) were created. There were more than 200 in the Delta compared to only 20 during the time of the Ardo. To make matters worse, arbitrary fees were introduced, collected and used for personal subsistence and prestige. 


\section{The 'jom sarré'/'bessema'}

Also known as 'masters of the land', the bessema is generally a former captive of the family of Diowro (Dimadio), given the responsibility by the latter to manage cultivation plots. Their power was quite limited.

\subsubsection{Customary rules and practices about managing natural resources in the Delta} Customs have a major influence on the management of production systems and resources in the Delta. The importance of these resources, their seasonal and spatial variations influence the relations of the users with the resource and the relations between actors. Customs often exist in the form of oral agreements between the stakeholders and agreement on guidelines. In this regard, we mainly consider the following principles:

Priority recognition of customary law and institutions for access to water resources: the users first ensure compliance with the customary procedures on access and use of resources by consulting traditional managers before referring to the administration and technical services responsible for the management. Moreover, relationships, notably among the fishing communities, are such that the usage rights established with some foreign fishermen are renewed each year as long as there are no issues with the 'masters of water'.

Precedence of traditional managers: the custom requires that the 'master of water' enters first then he opens up access to others. He regulates the collective use of the water bodies by assigning each group of fishermen a section of the water.

Existence and recognition of prohibitions: customs have restrictive rules with respect to fishing practices, grazing and agriculture. These cover periods, days and times of fishing, fishing zones, use of certain practices, capture of certain species during certain periods and admission of animals prior to withdrawal of water or crops.

Mobility of animals: this is a principle of livestock management customarily accepted due to natural resource constraints and the need to preserve social peace in the Delta. During the era of the Dina, mobility was carefully organized with a clear definition of transhumance paths and stage shelters in the Delta When the rainy season sets in, herders have to leave for transhumance between the months of August and September.

Reciprocity: the movement between the IND and the dry areas is based on the mutual interdependence of resources. During floods, livestock in the Delta move into these areas in search of water and pasture. When waters recede, reverse movement of animals from the Mema and Seno takes place thereby swelling the herds in the Delta in search of pasture in the fodder banks and water in the numerous surface water points. This solidarity in the 
region is strengthened after the degal, a major event marking the return of livestock. It further strengthens the relationships among the communities.

Interdependence and integration of space and activities: water is the main determinant of this link. The end of an activity results in the suspension of power over the resources and the beginning of another. For example, when water recedes, the Dioro manages the fodder banks and the 'master of water' suspends his power until the next flood. The 'master of land' distributes rights to farmers and controls land tenure.

\subsubsection{Degradation of traditional institutions and conflict over resource management}

Up to a certain period before independence in Mali, the relationship between the masters of the land, pastures and water bodies was quite clear regarding the limits of their rights and powers and their scope. Everyone was responsible for his domain. However, today, the relationships have been disrupted due to (i) the intrusion of the State in managing local affairs, (ii) corruption, (iii) land disputes, and sometimes (iv) greed. All these are exacerbated by resource degradation due to climatic factors. The local adage "he who has land, has a war", aptly describes the Delta as the zone has experienced bloody conflicts that have sometimes resulted in loss of lives and serious injuries as a result of disputes over land, fodder banks and fisheries.

Although the nature and extent of the conflicts varies, a number of them can be identified. Disputes between farmers are by far the most frequent and involve claims of ownership. Others are disputes between farmers and herders, disputes between herders, conflicts between fishermen, disputes between fishermen and herders and conflicts between different village communities. The conflicts arise manly due to claims to property rights on land based on the rights accorded through first occupation. The causes of conflict over natural resources in the Delta range from internal or external factors, institutional and socio-economic factors as well as a crisis within the traditional value system. They can be summarized as follows: (i) inadequacy of the law, (ii) mismatch between population growth and degradation, the narrowing of cultural space and modern means of exploitation, (iii) development of unplanned works by some projects, (iv) non-intervention of the State upon the occurrence of conflict to exercise its sovereign right as the sole owner of the land, (v) obviously unfair or erroneous court decisions.

\subsection{Production systems and economic activities}

Three production systems are found in the Delta: (i) agricultural system dominated by rice production, (ii) pastoralist system with breeding of herds of cattle and, (iii) fisheries system. These systems all have sub-systems or variants which are generally characterized by low level of use of equipment, low use of inputs, low number of the local workforce and, decline of pastoral resources, fisheries and soil fertility. The pattern of land use over 
time has been affected by high human population growth, climate change and management infrastructure.

\subsubsection{Rice production}

Rice is the dominant agricultural product in the IND and its production is practised in several forms:

Open submersion (RSL) is a practice, which requires no field preparation, consists of ploughing and sowing by spreading. Upon sprouting of seeds on the onset of rains, the cultivation practices involving weeding and fertilization (organic manure, mineral fertilizers) follow. The rice is directly irrigated by the river. The production is very uncertain and depends on the rains and floods. Although the system is widespread, the areas under this system do not benefit from supervisory support services. Production is low and varies from 0.6 to 0.9 tonnes per hectare.

Controlled submersion (RSC) is practised on fields with minimum preparation (water control structures and drainage channels) on the spaces provided adjacent to large rivers. The cultivation practices are similar to those of the free submersion. Production is also uncertain just as in free submersion since it depends to a certain extent on rains and floods such that the areas occupied range from 1,500 to 11,800 hectares depending on the year. The production of this system varies from 1,200 to 1,500 tonnes per hectare.

Submersion with total control of the water (RMT) is done on the developed areas with or without pumping water. Unlike the free submersion or uncontrolled flooding, rice is produced in nurseries and then transplanted to the plots. All cultivation practices are involved, i.e. ploughing, weeding, and use of fertilizer. The production is more certain than in the previous cases since the management of irrigation water is under control. From DRA data, it appears that in 2007, RMT-developed areas reached 1,293 hectares. This is the most efficient system in that RMT yields vary from 5 to 6 tonnes per hectare.

\subsubsection{Livestock keeping and pastoralism}

Livestock keeping is often cited as the second most important economic activity of the Delta after rice farming. The pastoralist and agro-pastoralist systems are characterized by double transhumance viz: (i) large transhumance from the Delta towards pasture on land where floods have receded (Seno, Plateau, Gourma), (ii) small transhumance referred to as internal transhumance in the Delta from Diafarabé (and Sofara) to the pastures of Lake Débo. Precedence rules allow the movement of herds of animals. However, the phenomena of poor rainfall and floods in addition to the problems of human and animal demography, social and sociological problems have disrupted the system and created conflicts by among other things changing the routes and even practices during periods of leaving fields lying fallow: 
people leave the Delta as late as possible (August-September) and enter the Delta as soon as possible (October-November).

Table 5: Livestock numbers in the Inland Niger Delta, 2007

\begin{tabular}{|l|c|c|c|c|c|c|c|}
\hline \multirow{2}{*}{ Locations } & \multicolumn{7}{|c|}{ Type of livestock } \\
\cline { 2 - 9 } & Cattle & Sheep & Goats & Camels & Poultry & Horses & Donkeys \\
\hline Djenné & 144,000 & 189,115 & 127,645 & 7 & 575,000 & 29,726 & 17,125 \\
Mopti & 312,000 & 226,815 & 206,504 & 515 & 645,000 & 4622 & 24,332 \\
Tenenkou & 146,000 & 84,999 & 32,855 & 172 & 305,000 & 2148 & 5533 \\
Youwarou & 139,000 & 119,952 & 134,030 & 44 & 325,000 & 1975 & 4475 \\
\hline TOTAL & 741,000 & 620,881 & 501,034 & 738 & $1,850,000$ & 38,471 & 34,340 \\
\hline
\end{tabular}

Source: DRPIA Mopti, 2007

Apart from poultry keeping (chickens, guinea fowl), which is practised by all households, cattle rank first among animal species reared with 741,000 heads. This number is a gross under-estimation $^{7}$ especially as the Inland Niger Delta is a refuge that supports most of the livestock from the Sahel that migrate temporarily to the Delta from neighboring regions (Segou and Timbuktu) and from as far countries as Mauritania, Niger and Burkina Faso. This number of 741,000 heads only represents estimates of animals belonging to indigenous farmers. An estimated 750,000 foreign cattle come into the Delta each year. There is therefore strong animal pressure ${ }^{8}$ on pastoral resources.

\subsubsection{Fishing}

The IND's main sources of water are the rivers Niger and Bani. It is characterized by a marked seasonal cycle resulting in differentiation of habitats (rivers, lakes, marshes, channels and floodplains). The main adaptation of the Sudano-Sahelian species to this changing environment appears in their large capacity to migrate laterally and longitudinally. This abundant resource has been heavily exploited for many years and fishermen have adopted specific production strategies based on the use of various fishing techniques adapted to different habitats and seasons. Given that the rivers are characterized by four main phases: floods, high water, recession and low water levels, and the presence of habitats described above, the result is a large inter-annual variability of fish populations. The migrations observed in fish are related to water movement and search for favourable areas for nutrition and reproduction. This variability of the environment and the resource has resulted in two types of behaviour among fishermen; the pursuit of fish synonymous with travel in temporary camps and/or use of a diverse array of fishing gear to exploit different habitats and different species depending on the season. Fishermen in the area of the Inland Niger Delta fall into four major groups: (i) Agrofishermen who carry out both farming and little activity on fishing. They are usually from

\footnotetext{
7 Livestock keepers only pay taxes on $1 / 3$ or even $1 / 10$ of their herd.

8 An estimated 1.5 million cattle and 750,000 sheep and goats are in transhumance in the IND (Source Dr N Diakite 2004 Study Report FODESA on pastoral resources).
} 
the Rimaïbe, Bambara, Marka and Sonraï ethnic groups. (ii) Full-time fishermen or Bozo who practise traditional dam fishing and use the river, (iii) Somono fishermen who specialize in river ecosystems and use the latest fishing techniques, (iv) Migrant fishermen or Bozo who sometimes embark on great migration from the upstream area of the Niger or Djenneri. Due to the importance of its water system (rivers, lakes, ponds, channels), fishing is by far the third most important economic activity of the Inland Niger Delta after agriculture and livestock. It is practised mainly on natural water bodies in the Inland Niger Delta where the catch varies from year to year depending on the rise and fall of water levels with a variable average of 70,000-120,000 tonnes of fish annually. The population of fishermen is estimated today at about 225,000 people distributed among two major ethnic groups: Bozo and Somono. This population which had 70,000 fishermen in 1967 was estimated at 225,000 fishermen in 1994, an increase of over $320 \%$ in less than 30 years.

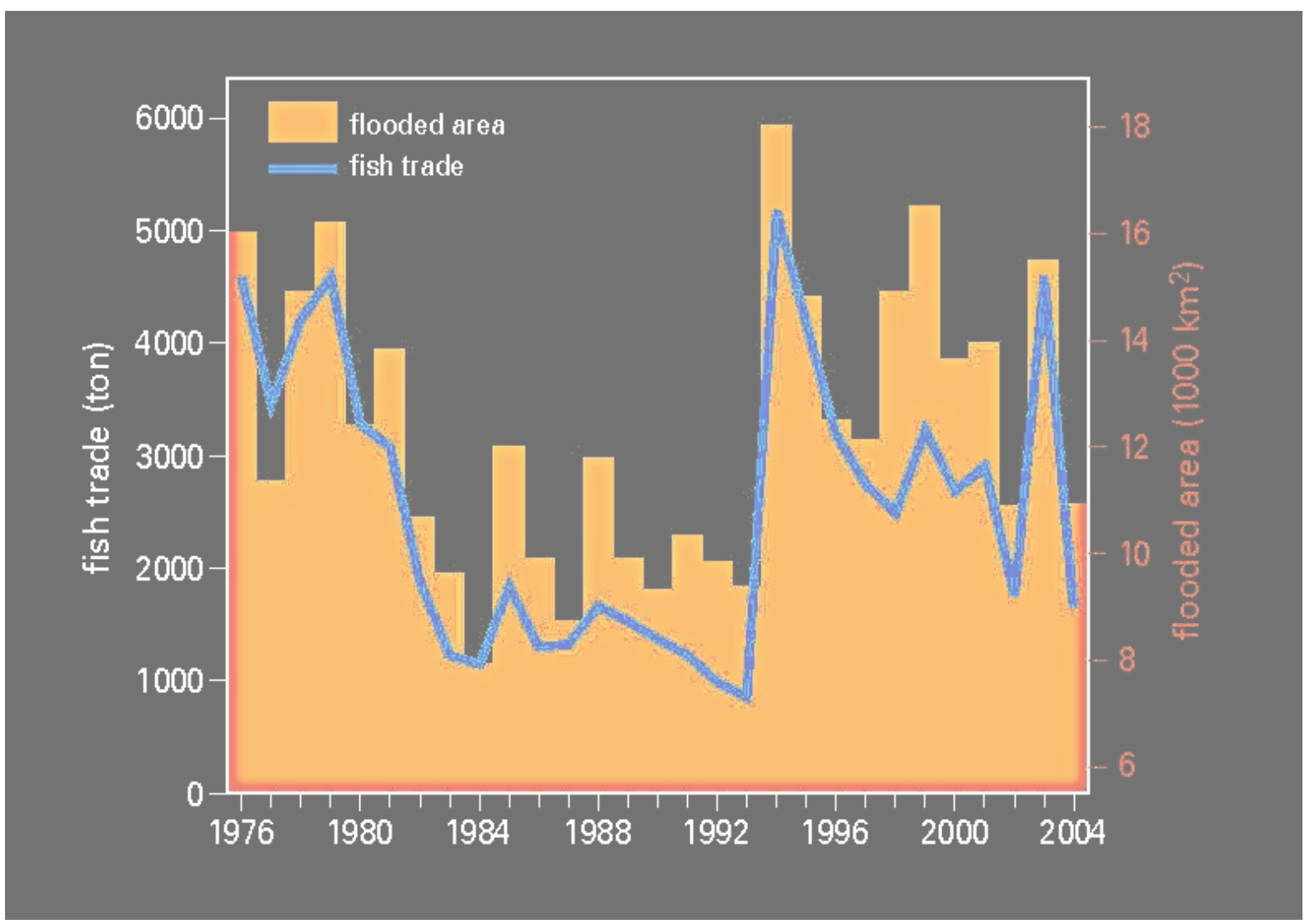

Figure 4: The fish production (source: DRP Mopti) is strongly linked to the flooded area in the Inner Niger Delta (from Zwarts et al. 2005) 
Table 6: Estimates of fish production of the Central Delta of Niger (1995-2009)

\begin{tabular}{|c|c|}
\hline Year & Production (in tonnes) \\
\hline 1995 & $\mathbf{1 3 1} \mathbf{0 0 0}$ \\
\hline 1996 & 96,000 \\
\hline 1997 & 82,015 \\
\hline 1998 & 81,697 \\
\hline 1999 & 84,714 \\
\hline 2000 & 92,377 \\
\hline 2001 & 85,316 \\
\hline 2002 & 89,570 \\
\hline 2003 & 80,798 \\
\hline 2004 & $\mathbf{6 1 , 0 7 3}$ \\
\hline 2005 & 63,285 \\
\hline 2006 & 71,305 \\
\hline 2007 & 74,480 \\
\hline 2008 & 76,070 \\
\hline 2009 & 76,024 \\
\hline Source: DRP-Mopti, 2010 & \\
\hline &
\end{tabular}

Almost all the people interviewed during the study mentioned that floods and rains were abundant in the Delta in the past decades. The rains usually began in May and continued until end of October and, the floods occur from June to December. Herbaceous and woody vegetation was abundant. Today, strong human and animal pressures associated with climatic factors in particular, low rainfall and floods, blockage of forest water channels, fodder banks, ponds and flood plains have contributed to the degradation, if not the total disappearance of certain sites of fish resources, leading to a significant reduction in breeding and capture areas of fish resources in the Inland Niger Delta. Since the great drought of 1973, the effects of climate change have disrupted the regime of the Niger River and its tributaries, which now generally receive less rainfall each year. These low floods and the resulting early recession of waters have restricted the fodder banks which make up large pools of floodplains where a hydromorphic soil was formed rich in nutrients (plant debris, remains of the decomposition of dead animals, ashes from burnt vegetation, etc) which offer food to fish and is favourable to their de-multiplication. 


\section{POLICIES AND LEGAL SYSTEM OF RESOURCE MANAGEMENT IN THE DELTA}

The protection and conservation of natural resources in the Inland Niger Delta is governed by the policies and strategies set out by the Government of Mali on the one hand, and a number of national laws and regulations on the other hand.

\subsection{National policies and strategies on natural resource management in the Delta}

Natural resources in Mali and the Inland Niger Delta in particular are governed by multiple policies and regulations, some of which overlap with one another. In the context of natural resource management, the most relevant of these policies and strategies in the Delta include the following:

\subsubsection{Strategic framework for growth and poverty reduction 2007-2011}

Its formulation dates back to early 2000 when the Government of Mali, with encouragement from technical and financial partners, decided to develop the Strategic Framework for the Fight against Poverty (CSLP) as part of its unique medium term policies and strategies and the main negotiating document with all the technical and financial partners. The CSLP expresses the Government's will to engage in more intense, more organized, consensual and efficient development action that is able to reduce poverty in a sustainable manner. The CSCRP II prescribed in its priority areas of intervention protection of the environment and better management of natural resources, the restoration and recovery of degraded areas and sites, the preservation, the management of natural resources and wildlife and the fight against desertification. Some of the challenges in the design and implementation of CSCRP are: (i) while it is agreed in the framework that the regional economy is based on natural resources, the budget allocation to planned investments in the development of natural resources is relatively low, (ii) there are no indicators to monitor the management of natural resources, especially in an area with rich and sensitive ecosystems such as the Inland Niger Delta. The CSCRP would gain a lot by focusing on investments in the sustainable management of natural resources for growth and socio-economic development and poverty reduction.

\subsubsection{National Policy for the Protection of the Environment (PNPE)}

This policy framework was adopted in 1998 for planning and sustainable management of the environment and natural resources. The PNPE is inspired and influenced by the Conventions, Agreements and International Treaties (CATI) ${ }^{9}$ ratified by the Government of Mali. In its objectives, it aims to: develop and support the implementation of a decentralized and participatory management of renewable natural resources, promote

\footnotetext{
${ }^{9}$ These include: the United Nations Framework on Climate Change (UNFCCC), the United Nations Convention to Combat Desertification (UNCCD), and the Convention on Biological Diversity (CBD)
} 
sustainable agricultural production systems that respect the environment, implement participatory projects/programmes of natural resource management to reduce the effects of desertification and/or drought, build capacity of actors. The principles of PNPE include prevention and precaution in environmental management, the internalization of environmental costs and enforcement of the principle of "polluter pays". To achieve its objectives the PNPE has developed and implemented nine programmes ${ }^{10}$

\subsubsection{National Sanitation Policy (PNA)}

The PNA subscribes to several agreements, treaties and international conventions including: the Vienna Convention and Montreal Protocol on Substances that Deplete the Ozone Layer, the Bamako Convention on the banning of the import of hazardous waste and the control of trans-boundary movement and management of hazardous waste within Africa, the Stockholm Convention on Persistent Organic Pollutants (POPs) etc. The PNA is based on six strategies including the national strategy for solid waste management, the national strategy for managing hazardous waste, the national strategy for liquid waste management, the national strategy for rainwater management, and the National Policy on Health and Environment.

\subsubsection{National Water Policy (PNE)}

The development of the PNE was motivated by Mali's membership in the Integrated Management of Water Resources (GIRE) initiated in 1996 by the Global Water Partnership (GWP) whose objective is to promote integrated water resources management (GIRE) and ensure a coordinated development and management of water, land and related resources, whilst maximizing the economic and social welfare without compromising the sustainability of vital ecosystems. The implementation of the PNE was translated by the creation of the Niger River Basin Agency (ABFN). The overall objective of the PNE adopted in 2006 is to contribute to the socio-economic development of the country by offering appropriate solutions to problems related to water, in accordance with sustainable management of water resources. Its specific objectives are among others: (i) to meet the water needs of a growing population in quantity and quality as well as ensuring respect of aquatic ecosystems and maintaining the needs of future generations, (ii) to contribute to the development of agro-pastoral activities. The participation of all stakeholders, rational use of water, preservation of balance of ecosystems, sub-regional and international cooperation are among the principles set by the PNE. One of the challenges in the implementation of the PNE is that the water sector is managed by several ministries (Ministry of Environment and Sanitation, Ministry of Agriculture, Ministry of Water Resources and Ministry of Public Health thereby creating a problem of coordination and articulation of joint actions at the grassroots by the actors.

\footnotetext{
${ }^{10}$ Water Resources Control Programme, Environment Information Management Programme, Environment Information, Education and Communication Programme, Programme for Monitoring the Implementation of Conventions, Agreements and Treaties.
} 


\subsubsection{National Action Plan for Climate Change Adaptation (PANA)}

Like other locations in Mali, the IND is characterized by a high inter-annual and intraseasonal variability of rainfall as well as a large variability within each of the four climate zones. Thus, the PANA created in 2007, forecasts an increase in temperature, a reduction in rainfall and increased frequency and magnitude of extreme weather phenomena. The mitigation or adaptation to climate change projects are being supported by some technical and financial partners.

\subsubsection{National Policy on Livestock Development (PNDE)}

Livestock keeping is the second most important economic activity among communities in the IND. As such, it plays a fairly important role in the regional economy. The birth of PNDE dates back to the advent of the Ministry of Livestock and Fisheries (MEP) The strategic intervention of the PNDE is based on development of pastoral resources, sustainable management of pastures and the developed water sources, elaboration of pastoral development plans, restoration of degraded lands and monitoring of pastoral ecosystems, fight against bush fires, regeneration and enrichment of rangelands. Many of the projects/programmes planned under the policy are still at the embryonic stage given that the department is still at the infancy stage. There is also overlapping of functions and jurisdictional disputes between the department of water and forest and the department in charge of livestock since the delineation of forest and pastoral spaces are ambiguous. The legal instrument of the PNDE, Law No. 01-004 under the pastoral charter is hardly operational for lack of enforcement legislation on the management of transhumance which remains a culture, a way of life and survival strategy of pastoralist communities in the Delta. There is a gap between traditional management of pastoral resources still under customary tenure (the Dina) and the law conferring the management to local authorities and the State resulting in the many conflicts experienced.

\subsubsection{Fisheries and Aquaculture Development Policy}

Like the PNDE, this policy was formulated following the establishment of the MEP. It was timely for the Delta in that it is one of the premier inland fisheries production areas in Africa, with production reaching 130,000 tonnes of fish annually. Fishing also employs about one-third of the population with about 300,000 professional fishermen of which 105,000 are residents ${ }^{11}$. The fisheries and aquaculture development policy aims to: increase the contribution of fisheries to the national economy and improve the living conditions of fishing communities, increase the contribution of the sub-sector to the satisfaction of food needs of the country, promote sustainable fisheries development, conserve biodiversity and restore ecosystems. Through the implementation of this policy a number of programmes were initiated including: Central Niger Delta Inland Fisheries Development Project (PADEPECHE), and the Niger River Basin Traditional Fisheries

\footnotetext{
${ }^{11}$ Strategic Development Plan Report of the Region of Mopti, Dec. 2008
} 
Development Project. The Law 95-031 establishing the conditions for fishing and fish farming remains the legal instrument for implementation of the policy. In the context of the IND, two sources of law still govern water bodies and fisheries: customary and modern law. The former gives access and control of water bodies and fisheries through customary institutions called 'masters of water', whereas modern law states that the right to fish belongs to the State and Regional Authorities. The many conflicts of jurisdiction are due to the fact that modern law as a legal basis for management of resources is not well known to a virtually illiterate population and the customs though legitimate to some extent are not recognized by the Government. In addition, the DNPIA which is responsible for the implementation of the policy is still at a formative stage.

\subsubsection{National Strategy for Development of Irrigation (SNDI)}

The strategy aims at ensuring control of water in order to promote and guarantee food production. It prescribes strict adherence to the PNPE during hydro-agricultural development and use of water for irrigation and formally institutes Environmental and Social Impact Assessment (ESIA) of irrigation projects.

\subsubsection{National Strategy for Food Security (SNSA)}

The strategy is managed by the Commission for Food Security (CSA) whose mandate is to develop and ensure the implementation of the National Policy for Food Security. The SNSA envisages that by 2015 it will meet the cereal requirements of Mali and reduce poverty. In its guidelines and intervention strategies, the SNSA and the CSA aim to: develop irrigation schemes, ensure the establishment, reconstitution and good management of the national reserves and cereals banks, plan, coordinate and control operations to distribute food to the affected areas, etc. From the perspective of the institutional framework of food security, the system set up is sufficiently decentralized at various levels: at the regional level by the Regional Committee for Food Security (Region) (CRSA), at the cercle level by the Local Committee for Food Security (CLSA), and at the municipal level by the Municipal Committee for Food Security (CCSA).

\subsubsection{National Policy on Wetlands (PNZH)}

The IND is the largest inland wetland in West Africa covering $30,000 \mathrm{~km}^{2}$. This was one of the aspects that motivated Mali to become a member of the Ramsar Convention and develop a national wetlands policy. Adopted in September 2003, the PNZH is part of the Ramsar Convention and envisages that by 2025 , it will provide guidance to government action and communities in order to preserve and sustainably manage natural resources and biodiversity of wetlands. The specific objectives of the PNZH are to promote the creation of a national database on wetlands, promote conservation of biological diversity of wetlands, train and educate the public on the economic and socio-cultural value of wetlands, improve knowledge on wetlands in Mali and designate new Ramsar sites, strengthen the legal and regulatory measures on management of wetlands and ensure their 
enforcement. The risks of development of wetlands for irrigated agriculture are noted in the degradation of wetland habitats through uncontrolled clearing and excessive use of fertilizers and pesticides which destroy flora and fauna.

\subsubsection{National Strategy for Use and Conservation of Biological Biodiversity}

With its rich natural heritage marked by the existence of 1,730 species of woody plants, about 640 species of birds, over 130 species of terrestrial wildlife, over 140 species of fish (of which 24 are endemic) ${ }^{12}$, Mali is a member of the Convention on Biological Diversity. Since its ratification of the convention on 29 March 1995, the country embarked on the formulation of a National Strategy for Biological Diversity accompanied by an Action Plan aimed at establishing a directory of areas of interest for flora, wildlife and unique ecosystems; improving knowledge on the functioning of ecosystems and plant and animal species that are of ecological or economic interest; improving knowledge of the national gene pool of cultivated plants, wild species related to domestic animal breeds and wildlife; promoting the sustainable use of fauna and flora; ensuring conservation of local cultivated plants and endangered breeds.

\subsubsection{Domestic Energy Strategy (SED)}

The SED was developed in the early 1990s with the aim of contributing to environmental protection through the management of domestic energy, limit use of wood as a source of energy and increase the actual capacity of regeneration of natural forests and develop methods of operation that are less destructive. The implementation of the SED is currently done by the Malian Agency for the Development of Domestic Energy and Rural Electrification (AMADER) whose principles include: understanding and support to the domestic fuel market, direct, make transparent and rationalize the use and trade in wood energy. The legal instrument for the implementation of the SED is Law No. 10-028PR-M of 12 July 2010 establishing the conditions for management of national forest resources. This is a relatively new law that repeals Law No. 95-003 of 18 January 1995 on the organization of the use, transport and trade on wood and Law No. 95-004 of 18 January 1995 establishing the conditions for forest management. The SED capitalizes on the first experiment conducted by the Wood Fuel Unit (CCL) which allowed the creation of several rural wood markets.

\subsection{Legal Texts and Decrees on Natural Resource Management in the Delta}

In similar fashion where there are numerous policies and strategies for resource management in the Delta, the legal texts (laws, decrees, orders) emanating from the

\footnotetext{
${ }^{12}$ Cf Working Paper: National Conference of the Environment. MEA, June 09.
} 
policies are very prolific ${ }^{13}$. Though not exhaustive, the relevant laws and regulations established for the management of natural resources in the Delta include:

- Law No. 10-028 P-RM establishing the conditions for managing the resources of the national forestry sector

- Law No. 02-006/of 31 Jan 2002 establishing the Water Code

- Law No. 01-004 P-RM under the pastoral charter in the Republic of Mali

- Law No. 01-020 on pollution and nuisances and its enforcement regulations

- Order No. 00-27/P-RM establishing the Code on Land and State owned Land

- Law No. 96-050 establishing the principles of constitution and management of regional authorities

- Law No. 95-032 establishing the conditions for fisheries management and fish farming

- Law No. 95-031 establishing the conditions for wildlife management and habitat.

In principle, the various laws establish the right of all citizens to live in a healthy environment, the duty of every citizen to protect natural resources and the environment, the right to access and use of resources in accordance with the standards and in a spirit of justice and equity, protection and conservation for present and future generations, rationality in the use of natural resources, the obligation to conduct ESIA in the design and implementation of any project likely to cause harm to natural resources and environment, the obligation to preserve the environment in the performance of rural activities by the State and the regional authorities, the principle of precaution with regard to the environmental degradation resulting from certain activities, the principle of "polluter pays" in environmental management, consultation and participation of stakeholders (State, regional authorities, natural or artificial persons) in the management of natural resources.

In practice, the legal texts are faced with challenges including the following:

- Low compatibility of texts with local realities, especially the customs governing access to and control over resources.

- Multiplicity and coherence between the legal texts: the texts are many and varied and are thus not well understood by the same agents in charge of their enforcement on the field. There are therefore several grey areas within the texts, interference and conflicts of jurisdiction between the agents.

\section{- Low level of dissemination}

- Empowerment of the poor people in resource management: resources have not been devolved to the people or the regional authorities. The central government manages the ownership and control of most of the national resources.

\footnotetext{
${ }^{13}$ Over 100 were counted.
} 
- Tenure insecurity: theoretically all natural resources without exception belong to the State in accordance with the philosophy that "vacant land without owners is the property of the State" as enshrined in the Land Code ${ }^{14}$. Although the Code establishes the recognition of customary rights to resources including land, procedures and mechanisms for recognition and registration of these rights remain complex, costly and time consuming

\subsection{Economic incentives to support environmental management}

The goods and services (regulation) services provided by ecosystems of the Delta include ground water recharge, nutrient retention and water purification. In terms of providing services, the Delta enables food supply and agricultural farming. In terms of cultural services, the ecosystems of the Delta support traditional ceremonies like collective fishing and boat races. On supporting habitats and biodiversity, the Inner Niger Delta offers tremendous potential for habitat diversity and fauna. In contemporary time, the main stakeholders in the delta (fishermen, cattle breeders and farmers) are increasingly realizing that water and its natural resources are finite as opposed to the previous idea that God is the Provider. They understand that the need to change human behaviour is crucial.

However, the use of economic instruments to bring about this change in behavior is rather low. At the national level, the economic instrument being implemented is "planting trees for self reliance". The project is a demonstration of the political will to combat desertification and support natural resources protection. The instrument had some success in the past, but also encountered several challenges. Apart from this project which is not yet fully functional, there is no economic incentive in policy promotion at national level. This is more so given that the budget allocated to the Environment Department which focuses on natural resource management and environmental protection is minimal, estimated at only about $1 \%$ of the national GDP.

However, at the local level, there are many economic incentive instruments being promoted by local NGOs to contribute to effective environment policy. Among these economic instruments and payments for ecosystem services (PES) are the Bioright approach, ensuring that environmental stewardship becomes a condition for access to microfinance institutions, Cereal Bank, and rice huskers for women association.

In terms of the potentials, there are many institutions that could readily implement policy and economic instrument to facilitate environmental management in the Delta. Among these, one can cite several national institutions, NGOs, and more recently administrative municipalities. Their capacities to do so, however, differ from one institution to another, due to the differences in their background, their technical ability and competence of their

\footnotetext{
${ }^{14}$ Cf Order No. 00 - 27/P-RM establishing the code on Land and State-owned Land in the Republic of Mali
} 
staff. Some NGOs that have implemented economic instruments to support environmental stewardship in the delta include CARE Mali, Wetlands International and Oxfam. 


\section{DEVELOPMENT CHALLENGES AND CONSTRAINTS TO NATURAL RESOURCE MANAGEMENT}

Due to its great potential in natural resources, the Delta is certainly the most productive zone in Mali. Yet the inhabitants in the region are some of the poorest in the country. The Inland Niger Delta has been a focus of many projects and programmes since the early days of independence, and efforts have been directed to improving the economic, social and cultural wellbeing of the population. An inventory of the economic, social, cultural and institutional situation reveals that at the economic level, there is a general downward trend in production and productivity of resources (land, water, fish, and pasture). From the perspective of social and cultural development, the persistence of bad practices and customs related to resources exacerbates social conflict, social exclusion and inequality. At a political and institutional level, problems experienced relate to inadequacy and inconsistency of policy and legislation to local realities, the poor long-term vision of development, the weak or lack of synergies of coordination and consultation among stakeholders who support development and inadequate human and material resources to ensure provision of public service by the State. The specific development challenges are highlighted below.

\subsection{Climatic factors}

Floodwaters of the Niger used to reach so many and expansive areas so that the farmers could plant their crops, and animals could feed on pastures. With the advent of climate change, the floodwater level has become lower, implying that the area of land covered by floodwater is smaller. The space for economic activities has consequently greatly reduced in both absolute (area of land flooded) and relative terms (land are per capita).

Competition for resources was intensified as the population increased, and more people moved into the Delta which is the place where they could access water since other places were becoming drier.

The climate-induced challenges in the Inland Niger Delta include the following:

- Regular decrease in rainfall and high spatio-temporal variation

- Very high radiation throughout the year with little differentiated average temperatures

- Temperature increase from southwest towards northeast with maximum recorded during the year reaching or exceeding $45^{\circ} \mathrm{C}$, while the minimum is rarely below $10^{\circ} \mathrm{C}$

- High values of potential evapotranspiration (PET) due to high temperatures, low relative humidity and strong winds

- Persistent droughts from the 1970s resulting in significant rainfall deficits and changes in isohyets to the south, which has made migration an increasingly important strategy to tackle these new precarious climatic and environmental conditions. 
These variations in climate, in particular rainfall, has had a significant impact on agropastoral and fisheries production in the Delta. Less rainfall means less production. This can be confirmed by the analysis of some climate data ${ }^{15}$; in 1984 the rainfall was only 334 $\mathrm{mm}$ in Mopti and the subsequent flood was $261 \mathrm{~cm}$. The effect was the notorious reduction in production which was only 4,654 tonnes. On the other hand, in 1994 at the same station, there was exceptional rainfall measuring $640 \mathrm{~mm}$ with floods reaching a height of $642 \mathrm{~cm}$. Rice production was 102,706 tonnes, while that of the fish was 131,000 tonnes. From the relationship between cause and effect, it should be noted that natural factors are often exacerbated by human activities such as indiscriminate clearing and felling of trees, poor agricultural practices and overgrazing.

Liersch et al (2012) recently conducted a study in Mali to assess the expected vulnerability of food security to water management and population growth under climate change and variability in the Delta for the period 2011-2050. They found that water reservoir and climate change will have very important impacts on water inflow patterns into the Delta and as a result, on the extent and duration of the flooded surface area. This is expected to have critical implications on food production and the livelihoods of the inhabitants of the Delta. The simulations carried out by the researchers reveal that the projected climate change will lead to a significant reduction of peak discharges during the rainy season and hence serious losses of agricultural productivity in the Delta.

\subsection{Anthropogenic and institutional factors}

Three main production systems are found in the IND, namely the agricultural system dominated by rice cultivation, the pastoral system with cattle as the central pillar of the system and fishing. These systems all have sub-systems or variants but are generally characterized by low use of modern equipment, and farm inputs, few local personnel make up the workforce, and a decline in pastoral and fisheries resources. The methods and systems for agro-pastoral and fisheries production in the Delta are still traditional and despite the climatic changes observed, they are extensive and have changed very little over time. Combined with the effects of chronic bad weather and low floods, constraints and problems of agricultural development in the Delta include low fertility of soils due to the effects of wind and water erosion, low production arising from poor yields, little knowledge of water control as well as techniques for production, landlocked nature of the Delta making it difficult to access potential markets, insecurity of tenure and land conflicts, and high poverty among the farmers. The pastoral and agro-pastoral systems encountered in the Delta are characterized by the double transhumance: a major transhumance from the Delta to pastures where water has receded and a small transhumance from Diafarabé (and from Sofara) to the pastures of Debo. Precedence rules allow the movement of herds of animals. However, the phenomena of poor rainfall and floods in

\footnotetext{
${ }^{15}$ This data was provided by the existing technical services including Mopti Weather Station, the Regional Water Resources, the Regional Directorate of Agriculture, the Regional Directorate of Fisheries.
} 
addition to the problems of human and animal demography, social and sociological problems have disrupted the system and created conflicts by among other things changing the routes and even practices during periods when fields should lie fallow: people leave the Delta as late as possible (August-September) and enter the Delta as soon as possible (October-November).

The disturbances are also due to a flow of more and more animals in the Delta which is becoming a point of refuge in the Sahelian zone. Some institutional challenges related to livestock development include:

- Arbitrary collection of tolo, a grazing fee imposed by jowro and exacerbated by the monetization of the fodder banks leading to degradation of social relations. There has been a sharp deterioration of good practices and traditional values inherited from Dina. The shameless exploitation of pastures is contrary to the traditional customs where the jowro had the mandate of the whole community.

- Renewed outbreak of conflicts: these conflicts relate to claims of property title between jowros, succession disputes between jowros, land claims on resources, attempts to remove a jowro, a position held for life and governed only by traditional customs, violation of order of precedence at crossings or during movement of herds, etc.

- Strong intrusion by the political, administrative and judicial authorities in the framework of conflict resolution.

- Climate change: since the great drought of 1973, the effects of climate change have disrupted the regime of the Niger River and its tributaries, which now generally receive less rainfall each year. These low floods and the resulting early recession of waters, have restricted the fodder banks which make up large pools of floodplains where a hydromorphic soil was formed rich in nutrients (plant debris, remains of the decomposition of dead animals, ashes from burnt vegetation, etc) which offer food to fish and is favourable to their de-multiplication. Fish remains a common resource of great importance in fisheries ecosystems.

- Over-fishing and exploitative fishing practices such as the use of nylon nets in the 1970s led to the near-depletion of fish in the Inner Niger Delta significantly changing the system of use of resources in the delta (Lae et al., 1994). Excessive fishing in the Niger Delta fuels tensions and potential conflict.

- Customary law, which once contributed to the ecological and social balance, tends to be more and more alienated.

\subsection{Poor accessibility due to the landlocked nature of the Delta}

The road network in the Delta is very poor and due to permanent and temporary flooding, it remains one of the most isolated areas of Mali. The main viable tarmacked road is the national road (RN6) that connects Djenné to Konna in any season. The other roads are made up of tracks and paths which are impassable for much of the year (June to February). 
Thus, the means most used for transportation of persons, cereals and goods are canoes linking major cities and towns.

\subsection{Chemical and organic pollution of rivers}

Among the factors contributing to chemical pollution, are the uses of more and more pesticides and mineral fertilizers in agriculture such as persistent organic pollutants (POPs) whose use is exacerbated by the locust and bird control campaigns. Thus there have been serious cases of pollution of surface water or groundwater contamination by these chemicals. Wildlife and fish also suffer heavily due to the use of insecticides, pesticides and fertilizers. Other methods of chemical pollution is several craft activities such as dyeing, soap making and tanning which often use highly toxic substances such as sodium hydroxide, sulfuric acid, lead chromate, animal and vegetable fats, which are discharged into waterways. These products are all harmful to human health and animal biodiversity, especially fish and water birds. Organic pollution also occurs mainly due to high demographic increase which imposes a high strain on infrastructure.

The appearance of invasive plants in the Delta is quite recent. The main plants are the Pistia stratiotes, Salvania molesta and Eichhornia crassipes. These plants can cause significant harm to ecosystems and biodiversity. Environmental problems caused by invasive plants are currently the cause of social problems (diseases), economic problems (degradation of fisheries, rice fields and pastures, navigational difficulties) and ecological problems (degradation of indigenous flora and fauna). 


\section{MAIN ORGANIZATIONS OPERATING IN THE DELTA}

\subsection{Public institutions}

\subsubsection{Ministries with oversight responsibilities in the Delta}

Table 7: Public ministries overseeing developments in the Delta

\begin{tabular}{|c|c|c|c|c|}
\hline \multirow{2}{*}{$\begin{array}{l}\text { Resource } \\
\text { Types }\end{array}$} & \multirow[t]{2}{*}{ Supervising authority } & \multicolumn{3}{|c|}{ Responsible institution in the Delta } \\
\hline & & Region & Cercle & District \\
\hline Water & $\begin{array}{l}\text { Ministry of Water } \\
\text { Resources } \\
(\mathrm{MH})\end{array}$ & $\begin{array}{l}\text { Regional Directorate } \\
\text { of Water Resources } \\
\text { (DRH) }\end{array}$ & $\begin{array}{l}2 \text { agents only for the } \\
\text { cercles of Mopti, } \\
\text { Djenne, Tenenkou and } \\
\text { Youwarou }\end{array}$ & Absent \\
\hline Environment & $\begin{array}{l}\text { Ministry of Environment } \\
\text { and Sanitation } \\
\text { (MEA) }\end{array}$ & $\begin{array}{l}\text { Regional Directorate } \\
\text { of Sanitation and } \\
\text { Control of Pollution } \\
\text { and Nuisances } \\
\text { (DRACPN) }\end{array}$ & $\begin{array}{l}\text { Local Department of } \\
\text { Sanitation and Control } \\
\text { of Pollution and } \\
\text { Nuisances }\end{array}$ & Absent \\
\hline Wildlife & $\begin{array}{l}\text { Ministry of Environment } \\
\text { and Sanitation } \\
\text { (MEA) }\end{array}$ & $\begin{array}{l}\text { Regional Directorate } \\
\text { of Water and Forests } \\
\text { (DREF) }\end{array}$ & $\begin{array}{l}\text { Local Department of } \\
\text { Water and Forests } \\
\text { (SLEF) }\end{array}$ & $\begin{array}{l}\text { Forest Office } \\
\text { (ALEF) }\end{array}$ \\
\hline Forests & $\begin{array}{l}\text { Ministry of Environment } \\
\text { and Sanitation } \\
\text { (MEA) }\end{array}$ & $\begin{array}{l}\text { Regional Directorate } \\
\text { of Water and Forests } \\
\text { (DREF) }\end{array}$ & $\begin{array}{l}\text { Local Department of } \\
\text { Water and Forests } \\
\text { (SLEF) }\end{array}$ & $\begin{array}{l}\text { Forest Office } \\
\text { (ALEF) }\end{array}$ \\
\hline Pastures & $\begin{array}{l}\text { Ministry of Livestock and } \\
\text { Fisheries } \\
\text { (MEP) }\end{array}$ & $\begin{array}{l}\text { Regional Directorate } \\
\text { of Production and } \\
\text { Animal Industries } \\
\text { (DRPI) }\end{array}$ & $\begin{array}{l}\text { Local Department of } \\
\text { Animal Production } \\
\text { and Industries } \\
\text { (SLPIA) }\end{array}$ & Absent \\
\hline Fish & $\begin{array}{l}\text { Ministry of Livestock and } \\
\text { Fisheries } \\
\text { (MEA) }\end{array}$ & $\begin{array}{l}\text { Regional Directorate } \\
\text { of Fisheries (DRP) }\end{array}$ & $\begin{array}{l}\text { Local Department of } \\
\text { Fisheries } \\
\text { (SLP) }\end{array}$ & $\begin{array}{l}\text { Local Fisheries } \\
\text { Branch } \\
\text { (ALP) }\end{array}$ \\
\hline $\begin{array}{l}\text { Agricultural } \\
\text { land }\end{array}$ & $\begin{array}{l}\text { Ministry of Agriculture } \\
\text { (MA) }\end{array}$ & $\begin{array}{l}\text { Regional Directorate } \\
\text { of Agriculture (DRA) }\end{array}$ & $\begin{array}{l}\text { Local Department of } \\
\text { Agriculture } \\
\text { SLA }\end{array}$ & $\begin{array}{l}\text { Local } \\
\text { Agriculture } \\
\text { Branch } \\
\text { (ALA) } \\
\end{array}$ \\
\hline $\begin{array}{l}\text { Forests, } \\
\text { Wildlife } \\
\text { Environment } \\
\text { Agriculture }\end{array}$ & $\begin{array}{l}\text { Ministry of Agriculture } \\
\text { (MA) }\end{array}$ & $\begin{array}{l}\text { Regional Centre for } \\
\text { Agricultural Research } \\
\text { (CRA) }\end{array}$ & Absent & Absent \\
\hline
\end{tabular}

The public management of natural resources in the Delta is handled by four key ministries, their central departments and national directorates. These are government structures devolved from various central departments attached to ministries involved in natural resource management and environment. These public bodies are represented at a regional and local level (cercles and rural district). Great efforts have been made to devolve the system and thus ensure representation. 
In addition to the above public institutions, one may add the Niger River Basin Agency (ABFN)- created in March 2002, under the auspices of the MEA. Its mission is to ensure the protection of the Niger River as a vital entity in the country, to protect its banks and watersheds against erosion and siltation and preserve the terrestrial and aquatic ecosystems. Another institution is the Agency for Environment and Sustainable Development (AEDD) created in 2010. Under the supervision of the MEA, its mission is to ensure coherence of environmental projects and programs with the National Policy on Environmental Protection (PNPE) and the International Conventions. It aims to ensure a harmonious, cohesive and participatory development that takes into account economic, environmental and social dimensions. AEDD has developed a guide to enact binding rules, standards and procedures. It is mainly a technical tool that provides a set of principles to be observed, approaches and actions to take in order to ensure consistency in the initiatives and measures to protect the environment. It applies to all programmes/projects regardless of their sources, status or quality. The objectives of the guide are among other things, to ensure the compatibility of the development projects implemented in Mali with key regulations and the National Policy for Environmental Protection (PNPE), rationalize the use of resources and planning tools in environmental management, ensure simplification of alignment procedures and greatly reduce approval times for requests made by project sponsors.

\subsubsection{Government directorates and their responsibilities in resource management}

Several directorates of public ministries are responsible for policy oversight related to natural resource management in the Delta. The specific responsibilities of the public directorates are explained below. 
Table 8: Public directorates and departments involved in NRM in Mali

\begin{tabular}{|c|c|}
\hline Institution & Summary of activities \\
\hline DRH & $\begin{array}{l}\text { - Evaluate potable water potential } \\
\text { - Collect, process and disseminate information on water } \\
\text { - Ensure coverage of safe drinking water needs } \\
\text { - Support regional authorities in the implementation of their water management } \\
\text { programme } \\
\text { - Protect water sources } \\
\text { - Ensure the implementation of the provisions of the law on management of water } \\
\text { - } \text { resources }\end{array}$ \\
\hline $\begin{array}{l}\text { DRACPN, } \\
\text { SLACPN }\end{array}$ & $\begin{array}{l}\text { - Promote the establishment of individual and shared sanitation facilities and provide } \\
\text { support to regional authorities in the field of waste management } \\
\text { - Identify the factors of pollution and nuisances and prescribe all appropriate measures } \\
\text { to prevent, reduce and eliminate them } \\
\text { - Ensure the enforcement, dissemination and compliance with laws and regulations } \\
\text { related to sanitation and fight against pollution and nuisances } \\
\text { - Develop and implement in collaboration with regional authorities and CBOs, } \\
\text { outreach and training programmes for citizens on the danger of pollution and ensure } \\
\text { their monitoring and evaluation }\end{array}$ \\
\hline $\begin{array}{l}\text { DREF, } \\
\text { SLEF and } \\
\text { ALEF }\end{array}$ & $\begin{array}{l}\text { - Ensure the implementation of development and restoration of forests, parks and } \\
\text { reserves } \\
\text { - Disseminate laws and regulations on the management of forest and wildlife } \\
\text { - Enforce laws and regulations relating to the conservation of forest and wildlife } \\
\text { resources } \\
\text { - Implement action programs to fight against desertification } \\
\text { - Support regional authorities in the management of forest resources and wildlife }\end{array}$ \\
\hline DRPIA, SLPIA & $\begin{array}{l}\text { - Ensure the monitoring and implementation of PNDE } \\
\text { - Monitor the implementation of pastoral development programmes in accordance } \\
\text { with the pastoral charter } \\
\text { - Ensure the development and management of pasture and pastoral water }\end{array}$ \\
\hline DRP, SLP, ALP & $\begin{array}{l}\text { - Ensure the monitoring and implementation of the national fisheries policy } \\
\text { - Ensure coordination and monitoring of the implementation of the said policy at a } \\
\text { regional and local level } \\
\text { - Ensure the enforcement of texts on fisheries } \\
\text { - Initiate local development plans for fisheries }\end{array}$ \\
\hline $\begin{array}{l}\text { DRA, SLA, } \\
\text { ALA }\end{array}$ & $\begin{array}{l}\text { - Ensure monitoring and implementation of measures and actions put in place to } \\
\text { increase production and improve the quality of agricultural goods, food and non-food } \\
\text { - Monitor the implementation of training, advisory and extension services and } \\
\text { - communication activities for farmers } \\
\text { - Ensure the enforcement of regulations on plant quarantine and packaging of } \\
\text { agricultural products } \\
\text { - Participate in the development and implementation of agricultural research policy } \\
\text { - Ensure the implementation of measures to enhance and promote products from } \\
\text { gathering } \\
\text { - Participate in the monitoring of quality standards for agricultural products and inputs } \\
\text { - Ensure the collection, processing and dissemination of agricultural data }\end{array}$ \\
\hline CRRA & $\begin{array}{l}\text { - Contribute to the definition and implementation of goals and means of research and } \\
\text { study in the service of agricultural development } \\
\text { - Develop and implement programs of agricultural research } \\
\text { - Proceed with the development of appropriate technologies for increasing production } \\
\text { - Disseminating the results of research and study }\end{array}$ \\
\hline
\end{tabular}




\subsubsection{Public and para-state projects and programmes}

A number of public and para-state projects are being carried out in the Delta to support development and natural resource management. Some of these are listed below. In addition, there are prospective projects planned for implementation in the Delta. These include the Support Project for Livestock Development in the Region of Mopti (PRODEM) and the Sustainable Development Project of the Inner Niger Delta (PDDIND) both of which are proposed by the MEA.

Table 9: Public and para-state projects and programmes

\begin{tabular}{|c|c|c|c|c|c|}
\hline No. & Project name & Status & Duration & Objectives & $\begin{array}{l}\text { Areas of } \\
\text { intervention }\end{array}$ \\
\hline 1 & $\begin{array}{l}\text { Development } \\
\text { Project of inland } \\
\text { fisheries in the } \\
\text { Delta } \\
\text { (PADEPECHE) }\end{array}$ & Public & 5 years & $\begin{array}{l}\text { Contribution to strengthening the } \\
\text { country's food security and poverty } \\
\text { reduction } \\
\text { Improving conditions for fish production } \\
\text { to meet food requirements and raising } \\
\text { the living standards of fishermen }\end{array}$ & $\begin{array}{l}\text { Mopti, Djenne, } \\
\text { Tenenkou and } \\
\text { Youwarou }\end{array}$ \\
\hline 2 & $\begin{array}{l}\text { Regional Authority } \\
\text { and Local } \\
\text { Development (CT- } \\
\text { DL }\end{array}$ & Public & 6 years & $\begin{array}{l}\text { Improving living conditions of } \\
\text { populations in a sustainable manner }\end{array}$ & $\begin{array}{l}\text { Regions of Mopti } \\
\text { and Timbuktu }\end{array}$ \\
\hline 3 & $\begin{array}{l}\text { Support } \\
\text { Programme for the } \\
\text { Agricultural Sector } \\
\text { in Mali } \\
\text { (PASAM) }\end{array}$ & Public & 4 years & $\begin{array}{l}\text { Contribute to the achievement of the } \\
\text { CSCRP and LOA, in particular } \\
\text { agricultural growth and poverty } \\
\text { reduction in rural areas. }\end{array}$ & $\begin{array}{l}\text { Tenenkou, } \\
\text { Youwarou }\end{array}$ \\
\hline 4 & $\begin{array}{l}\text { Support Project for } \\
\text { Rural Districts of } \\
\text { Mali (PACR-M) }\end{array}$ & & & $\begin{array}{l}\text { Contribute to poverty reduction in rural } \\
\text { districts in the region }\end{array}$ & Entire Mopti region \\
\hline 5 & FODESA Project & Public & 6 years & $\begin{array}{l}\text { Reduce poverty } \\
\text { Participatory and sustainable } \\
\text { management of natural resources }\end{array}$ & $\begin{array}{l}\text { Djenné, Mopti, } \\
\text { Tenenkou, } \\
\text { Youwarou }\end{array}$ \\
\hline 6 & $\begin{array}{l}\text { Competitiveness } \\
\text { and Diversification } \\
\text { of Agricultural } \\
\text { Products Project } \\
\text { (PCDA) }\end{array}$ & Public & 18 months & $\begin{array}{l}\text { Agriculture, Livestock, Fishing, } \\
\text { Microfinance, } \\
\text { Capacity building of stakeholders }\end{array}$ & Entire Mopti region \\
\hline
\end{tabular}

\subsection{Non-governmental organizations (NGOs)}

\subsubsection{NGOs operating in the Delta and their activities}

Several NGOs operate in the Delta and carry out a variety of activities.

Table 10: Examples of NGOs and activities carried out in the Delta

\begin{tabular}{|c|l|c|c|l|}
\hline No. & \multicolumn{1}{|c|}{ Name of Institution } & Status & Duration & \multicolumn{1}{c|}{ Activity sector } \\
\hline 1 & $\begin{array}{l}\text { Action for Rural Education and self- } \\
\left.\text { promotion (AFAR }{ }^{\mathrm{TC}}\right)\end{array}$ & National NGO & Indeterminate & $\begin{array}{l}\text { PPIV development; forest improvement; literacy; } \\
\text { microfinance; capacity building }\end{array}$ \\
\hline 2 & $\begin{array}{l}\text { Environmental Support Group } \\
\text { (GAE/WALIA) }\end{array}$ & National NGO & Indeterminate & $\begin{array}{l}\text { Environmental education; records of educational } \\
\text { material }\end{array}$ \\
\hline
\end{tabular}




\begin{tabular}{|c|c|c|c|c|}
\hline 3 & $\begin{array}{l}\text { Near East Foundation } \\
\text { (NEF-Mali) }\end{array}$ & $\begin{array}{l}\text { International } \\
\mathrm{NGO}\end{array}$ & Indeterminate & $\begin{array}{l}\text { Forests; pastures; agriculture; rural water supply; } \\
\text { micro-finance }\end{array}$ \\
\hline 4 & $\begin{array}{l}\text { Organization for Environmental } \\
\text { Management in the Sahel (ODI - } \\
\text { Sahel) }\end{array}$ & National NGO & Indeterminate & Water and Sanitation,; NRM; training \\
\hline 5 & Sahel-ECO & National NGO & Indeterminate & $\begin{array}{l}\text { Village water services ; forest village enterprises; } \\
\text { GRRN; pastoralism }\end{array}$ \\
\hline 6 & Wetlands International & $\begin{array}{l}\text { International } \\
\text { NGO }\end{array}$ & Indeterminate & Research; environment \\
\hline 7 & CISV & $\begin{array}{l}\text { International } \\
\mathrm{NGO}\end{array}$ & Indeterminate & $\begin{array}{l}\text { Livestock; agriculture; microfinance; processing } \\
\text { agricultural products }\end{array}$ \\
\hline 8 & $\begin{array}{l}\text { Integrated Management of Water } \\
\text { Resources of the IND (GIREDIN) - } \\
\text { PROTOS }\end{array}$ & $\begin{array}{l}\text { International } \\
\mathrm{NGO}\end{array}$ & Indeterminate & $\begin{array}{l}\text { Drinking water infrastructure; health } \\
\text { infrastructure; irrigation; research - action }\end{array}$ \\
\hline 9 & Catholic Relief Services (CRS) & $\begin{array}{l}\text { International } \\
\mathrm{NGO}\end{array}$ & 6 years & Education; hygiene; sanitation \\
\hline 10 & AMPRODE Sahel & National NGO & Indeterminate & $\begin{array}{l}\text { Education; environmental; health; development; } \\
\text { water; microfinance }\end{array}$ \\
\hline 11 & $\begin{array}{l}\text { Group for Research and Technology } \\
\text { Applications (GRAT) }\end{array}$ & National NGO & Indeterminate & $\begin{array}{l}\text { Hydro-agricultural development; market } \\
\text { gardening; strengthening capacities of actors }\end{array}$ \\
\hline 12 & $\begin{array}{l}\text { Rehabilitation of degraded ecosystems } \\
\text { of DIN (IUCN / REDDIN) }\end{array}$ & $\begin{array}{l}\text { International } \\
\mathrm{NGO}\end{array}$ & 3 years & $\begin{array}{l}\text { Research - actions; training; biodiversity; IEC; } \\
\text { training; strengthening capacities of actors; } \\
\text { supporting drafting of local agreements; } \\
\text { supporting development and management of PA }\end{array}$ \\
\hline 13 & $\begin{array}{l}\text { Development Project of the Inner Niger } \\
\text { Delta (CARE / PADIN) }\end{array}$ & $\begin{array}{l}\text { International } \\
\mathrm{NGO}\end{array}$ & 5 years & $\begin{array}{l}\text { PPIV development; promote local production } \\
\text { sectors; SNRM; IEC; promoting new energy; } \\
\text { infrastructure equipment }\end{array}$ \\
\hline
\end{tabular}

\subsubsection{Networks and platforms in the Delta}

There are multiple platforms and networks to improve coordination and synergy of activities that are implemented by the numerous public, para-state and private organizations and projects in the Delta. Some of these platforms are listed below.

\section{Table 11: List of platforms and networks in the Delta}

\begin{tabular}{|c|c|c|c|c|}
\hline No & Name of Institution & Status & $\begin{array}{l}\text { Date of } \\
\text { creation }\end{array}$ & Objectives \\
\hline 1 & $\begin{array}{l}\text { Regional Water Board or } \\
\text { Regional Water Partnership }\end{array}$ & Private body & 2006 & $\begin{array}{l}\text { Information } \\
\text { Creation of awareness } \\
\text { Training of stakeholders in the water sector } \\
\text { and sanitation }\end{array}$ \\
\hline 2 & $\begin{array}{l}\text { Regional Council of Civil } \\
\text { Society }\end{array}$ & Private body & 2006 & $\begin{array}{l}\text { Citizen watch } \\
\text { Monitoring and evaluation of CSCRP }\end{array}$ \\
\hline 3 & $\begin{array}{l}\text { Regional Coordination of } \\
\text { NGOs (CR - NGO) }\end{array}$ & Private body & 1997 & $\begin{array}{l}\text { Strengthening support and defence of its } \\
\text { members }\end{array}$ \\
\hline 5 & $\begin{array}{l}\text { Decentralized Management } \\
\text { Network of Natural Resources } \\
\text { in the } 5^{\text {th }} \text { Region } \\
\text { (GDRN5) }\end{array}$ & $\begin{array}{l}\text { Informal } \\
30 \text { NGOs } \\
\text { involved in } \\
\text { NRM in } 5^{\text {th }} \\
\text { Region }\end{array}$ & 1994 & $\begin{array}{l}\text { Provide a platform for exchanges between } \\
\text { NGO members } \\
\text { Lobbying/advocacy } \\
\text { Strengthening capacity of members }\end{array}$ \\
\hline 6 & $\begin{array}{l}\text { Association of Professional } \\
\text { Farmers Organizations (AOPP) }\end{array}$ & Private body & & $\begin{array}{l}\text { Set up a space for national consultation } \\
\text { between farmers' organizations in all regions }\end{array}$ \\
\hline
\end{tabular}




\begin{tabular}{|c|c|c|c|c|}
\hline & & & & $\begin{array}{l}\text { of Mali, agriculture } \\
\text { Promote a framework for discussion, } \\
\text { reflection and collective action for the OPs } \\
\text { Strengthen the legitimacy and credibility of } \\
\text { AOPP with the State, the PTFs } \\
\text { Manage and complete pilot activities at the } \\
\text { grassroots and use them as arguments during } \\
\text { negotiations with the authorities. }\end{array}$ \\
\hline 7 & $\begin{array}{l}\text { Regional Conference on fodder } \\
\text { banks }\end{array}$ & $\begin{array}{l}\text { Dialogue } \\
\text { between } \\
\text { administration, } \\
\text { technical } \\
\text { services and } \\
\text { farmers }\end{array}$ & 1966 & $\begin{array}{l}\text { Determine the timing of transhumance in the } \\
\text { DIN } \\
\text { Ensure the enforcement of transhumance } \\
\text { rules } \\
\text { Prevent conflicts }\end{array}$ \\
\hline
\end{tabular}




\section{DIAGNOSTIC TOOLS AND PLANNING MECHANISMS FOR RESOURCE MANAGEMENT}

\subsection{Diagnostic, planning and information tools}

Developed and promoted by research institutions and international organizations such as IRD, AGRHYMET, Wetlands International among others, some tools that help in decision-making have been developed over the last decade. These tools include, among others, SIMES, OPIDIN and SPIAC. These tools aim at informing policy and local actors on flood and drought forecasts in the IND. Most of the diagnostic tools are in the experimental stage as in the case of OPIDIN and SPIAC, and their level of use in the field is still limited. Furthermore the development of some tools such as SPIAC is still partial to the extent that during the validation workshop of the tool, reservations were expressed about the inclusion of certain parameters. Dating from the colonial era, there has been a challenge with the reliability of some of the tools and instruments used for measuring the level of water and flooding in the Delta. Serious doubts have been raised about the reliability of some diagnostic tools. For example, SPIAC under the control of AGHRYMET announced a good rainy season in 2011 but the season proved to be one of the worst in terms of lack of rainfall and flooding of rivers comparable only to the severe drought year of 1984. The process of developing SIMES by the Sub-Saharan Observatory faded halfway, for lack of funding. Some tools such as SIFOR, DELMASIG are and will continue to remain only internal instruments as long as their accessibility and level of use by local actors is limited.

\subsubsection{Multimedia Information System for the sub-Saharan Environment (SIMES)}

This information system was piloted by IER, Mali and IRD. For three years, the SIMES project supported the methodology and fieldwork that decisively contributed to the emergence of a body for continuous monitoring of fishing in the Inner Niger Delta. This body, also known as an "observatory" is intended to inform and support public, national and local policies, with a view to establishing sustainable management of this sector which has experienced enormous difficulties in the past but whose maintenance is vital for the region. The targeted beneficiaries are primarily the decision-making bodies and operators involved in the Delta (Council for Development of the Governorate, Mopti Fishing Operations, various Regional Directorates, NGOs and development projects), other beneficiaries include the central agencies and disseminators of information i.e. the Early Warning System, which focuses on the food situation of the regions, Planning and Statistics Unit of the Ministry of Rural Development, the National Directorate of Statistics and Informatics and finally, the community of scientists. The project had to stop in 2000 due to lack of funding. 


\subsubsection{Monitoring and prediction of water level in the Inland Niger Delta (OPIDIN)}

OPIDIN is a predictive model for forecasting of floods in the Delta when the water level begins to rise. The main objective of OPIDIN is to predict the level and period of the flood period and thereby allowing local communities to better plan their economic activities and the input for these activities. The tool has a table prediction maps and report. The basic data required for the tool are water levels, satellite images and IGN maps. The tool is the result of collaboration between Royal Haskoning, Altenburg \& Wymenga Ecological Wetlands International. The work was conducted within the framework of the project on wetlands and livelihoods: GIRE (Integrated Management of Water Resources) in the Niger basin upstream of Taoussa. Given the changes expected in the Inner Niger Delta due to climate change, this tool is useful since forecasts of floods will be more important in the future. In addition, OPIDIN can work as an early warning system and is therefore an essential tool for the population, be they fishermen or farmers as it will help them achieve food security. The current model is based on daily measurements of water level in Mopti and Akka (central part of the Inner Niger Delta) since 1956. The focal point of the OPIDIN is the DRHE Mopti. OPIDIN was tested in two villages in the Delta (Kakagnan and Akka) to monitor and inform fishermen and farmers on the evolution of floods. The results were quite convincing as a whole and a Steering Committee of the tool was set up. During the field study, the Governor of Mopti region is reportedly particularly interested in using the tool to help provide a sound evidence-based basis to make a decision on the proposed calendar of entry of animals in the Delta. The tool has been conceptualized and is presently being refined and tested on a pilot scale by key institutions including regional Directorates involved in natural resource management. These stakeholders are expected to further validate and disseminate the same to the wider public and users.

\subsubsection{Early Warning System (EWS)}

Following episodes of severe drought, 1973-1974 and 1984-1985, which had a dramatic impact on the populations of the Sahel and the difficulties encountered in the search for solutions, the governments of the region, supported by donors, highlighted the urgent need to establish early warning systems as well as systems for continuous, fast and efficient monitoring of food and nutrition security. Access to reliable data in near real time would enable the preparation of quick and effective solutions to food problems. Thus, the Ministry of Regional Authorities and donors founded the Early Warning System of the Republic of Mali. Under the supervision of the Food Security Commission (CSA) the EWS is responsible for responding to a set of questions about the status of food security:

- Which are the areas and populations likely to experience a food or nutrition crisis?

- From what time and for how long?

- What are the estimated needs?

Initially, only the areas north of $14^{\text {th }}$ parallel were considered at risk. However, since 1998, numerous surveys and studies have shown that the dietary risk had partly 
transformed; from an essentially rural and cyclical insecurity due to climatic factors to structural poverty both rural and urban.

\subsubsection{Flood Prediction System in the Delta (SPIAC)}

The SPIAC could be a tool whose use would allow the different stakeholders in the Delta to predict a high or low flood a few months or weeks in advance in order to take steps that can reduce its harmful effects. For its implementation the AGRHYMET in 2002 equipped the Regional Directorate of Hydraulics and Energy with information technology tools for capturing and disseminating information to stakeholders in the Delta. A training session on flood forecasting was organized for the implementing agencies of the Central Delta pilot project. The model, based on the flow of the flood from the Niger at Koulikoro and Mopti stations, did not take into account the Bani and its stations that also play an important role in the flooding of the Central Delta of the Niger River. Consideration of these observations will lead to a new model that will integrate the Bani, its flows and heights. To make this tool effective, it will be essential to design it from simple data and information that can help the people of the Delta to develop and adopt appropriate strategies. Two types of information can be useful to them: climatic data (rainfall, and floods) and agricultural data (agriculture, livestock and fisheries).

As a device or tool for information and warning the SPIAC can contribute to: making a right decision in time, development of a strategy for adapting to the difficulties by reducing their harmful effects or negative impact, stimulation of research, diversification of sources of income for farmers and strengthen their organizations, encouragement of increased production and thus ensure better management and encourage the preservation and restoration of the environment.

\subsubsection{Forest Information System (SIFOR)}

The Forest Information System (SIFOR) is a tool for capitalization, decision-making support and monitoring of changes in vegetation, and their productivity. It was developed after a forest inventory that was carried out in the 5th, 6th and 7th regions of Mali as part of the implementation of the Environmental Support Programme for the Fight against Desertification (PEALCD) funded by the European Union. Established with a view to integrating the forest data of the entire country, SIFOR is now the repository at the national level for the management and monitoring of natural resources. In addition to allowing the integration of data generated in the framework of the PEALCD and by other stakeholders, the SIFOR has the potential to provide the necessary information for the development of Supply Master Plans (SDA) of wood-energy and become the data base for the same; be a source of information for the departments in charge of rural development and land use planning, and in particular; assist in the design and implementation of the policy of decentralized management of natural resources as well as the development of regional development programmes and plans, become a portal for exchanges between 
development structures and those of research. Since June 2008, the Ministry of Environment and Sanitation (MEA) created within the National Directorate for Conservation of Nature (DNCN) a Management Unit to ensure its ownership of the tool, its management, development, promotion of its use and sustainability. SIFOR, as a decision making support tool on issues of wood energy and environment, ensures access to: detailed inventory of timber resources by region, cercle and district, volume tariffs by type of vegetation, vegetation maps, land tenure maps, alphanumeric and cartographic database

\subsubsection{DELMASIG}

DELMASIG is a decision-making support tool for agro-pastoral problems in the Inland Niger Delta. It allows the modeling of vegetation types of the Delta, predicting flooded areas based on flood heights in Mopti, and provides strategies for the use of space by rice farmers.

\subsubsection{Radarsat-2 and SPOT}

This tool monitors the evolution of flooding of the river using a high resolution radar and optical imaging to evaluate land use, assess the annual impact of flooding in the region and contribute to their forecast. It may help to improve the planning of development actions and facilitate management of water resources and related resources (Dezetter et al., 2011).

\subsection{Level of usage of the diagnostic and planning tools}

Most of the diagnostic tools are in the experimental stage. Some of the tools such as OPIDIN and SPIAC have not been widely disseminated to stakeholders for use in the field. Furthermore the development of some tools such as SPIAC is still partial to the extent that during its validation workshop, reservations were expressed about the inclusion of certain parameters. Questions on the reliability of certain water level measuring instruments (some dating as old as the colonial era) have been raised. Serious doubts have also been raised about the reliability of some diagnostic tools. For example, SPIAC under the control of AGHRYMET had announced a good rainy season for 2011. However, the season was one of the worst in terms of lack of rainfall and flooding of rivers comparable to the years of severe drought of 1984. Regarding the rest of the tools, the process of developing SIMES by the Sub-Saharan Observatory faded away midway due to lack of funding. SIFOR and DELMASIG are still internal tools since we do not control their level of accessibility and level of usage by the local actors. 


\subsection{Planning and resource management mechanisms in the Delta}

\subsubsection{District Plan for Environmental Action (PCAE)}

With the effective implementation of decentralization, it was necessary to give the local environment managers a reference tool adapted to the new context to replace the Local Action Programme (PAL). It was in response to this concern that AEDD in collaboration with three Research Departments, resource persons and support of Germany through GIZ produced a guide for the development of district programs for environmental action.

\subsubsection{Economic, Social and Cultural Development Programme (PDESC)}

The decentralization process affirms the Regional Authorities as owners of development in their respective domains. They are responsible for the planning of their development, particularly through the development and implementation of the Economic, Social and Cultural Development Programme (PDESC), which should translate a vision of development into concrete actions for the five years of an electoral mandate.

In its constant quest to improve support to the regional authorities (CT), efforts are being made to define a simple procedure of supporting the district planning process which is easily owned by the local actors. Designed from the experiences of each actor, this guide is intended primarily for elected leaders and district officials who should lead the process of developing the PDESCs at district level. Secondly, professionals from the decentralization support organizations and officers from the technical departments that would like to support a district in the development of its PDESC. The PDESC guide also comes with a brief synopsis of the objectives and methods of each phase and stage of the process. This form of presentation is chosen to facilitate information and stakeholder participation in the PDESC development process and also to increase ownership of procedures and tools. This document is intended to serve as an "aide-mémoire" for those involved in the PDESC development process in order to encourage active participation in various activities. Thus, the PDESC is applicable to different levels of decentralization namely: region, cercle and district.

\subsubsection{Steering, coordination and monitoring of development actions committees} The Committees comprising CROCSAD, CLOCSAD, CCOCSAD created by decree 0895 of 21 February 2008, mission of the Committees is to promote synergy of development activities of the various stakeholders. Among others, their functions are to advise on development strategies and programmes, ensure consistency in the implementation of sectoral programs, direct, coordinate, monitor and evaluate the necessary support to the implementation of development programmes of the regional authorities.

Under the chairmanship of the administrative authorities (Region Governor, Prefect and Ministerial representative) in their domains, working committees were established, 
namely: Rural Economy which includes environment and natural resource management and takes up the potential role of coordination frameworks to ensure coherence in the actions of public and private stakeholders on the one hand, and monitoring and evaluation of the same stakeholders on the other hand; Secondary Sector made up of infrastructure, facilities and physical planning, Sustainable Human Development and Communication, and Institutional Development, Decentralization, Devolution and Governance.

The positive effect linked to the creation of coordination frameworks to promote a coordinated approach to development is the repeal of the earlier texts in regard to the sectoral regional and local committees, and the creation of development planning committees such as CROs and CLO among others. The main difficulty of coordinating and monitoring development activities is that it is based on volunteer work leading to inefficiencies due to lack of financial resources. 


\section{SYNTHESIS OF LESSONS LEARNT}

\subsection{Strengths and opportunities}

The main strengths and comparative advantages of the region deserve special attention. They include:

\subsubsection{Geography}

The Inland Niger Delta is well placed geographically straddling between the north and the southern regions and borders Burkina Faso to the east and Mauritania to the west.

\subsubsection{Social and cultural life}

- Ethnic and cultural diversity: the Delta is multi-ethnic and rich in diverse cultures where one meets all the Sahelian ethnicities of Mali. This is the basis of a complex social diversity among the various communities with alliances and endo-ethnic and inter-ethnic cousinhood.

- Plurality of historical treasures: the Delta inherited rich and diverse civilizations, coming both from the North and the South. This gives it a uniqueness and specificity characterized by the wealth of Arab-Berber and Moroccan empires, the Bamanan de Ségou empires and Fulani empires of Macina and Toucouleur El Hadj Omar.

- Reciprocity, complementarity and solidarity in all systems of agro-pastoral and fisheries production.

\subsubsection{Economy}

- Great agricultural potential because of temporary or permanent availability of water and agricultural land. The Inland Niger Delta is one of the most productive areas of rice in the West African sub-region.

- Tourist attractions: with the classifying of sites in the city of Djenné (the religious city) as world cultural heritage sites and the city of Mopti (Venice of Mali) the Delta is one of the foci of tourism in Mali.

- Pastoral and livestock resources: due to the diversity and richness of its natural pastures, the Delta is an excellent livestock farming area and has the highest number of cattle and sheep/goats in Mali.

- Fishery resources: due to the importance of its water system (rivers, lakes, pools, waterways), fishing is the third most important economic activity of the region after agriculture and livestock farming with production ranging from 50,000 to 130,000 tonnes of fish per year. 


\subsubsection{Political and institutional environment}

- Existence of many political and legal mechanisms for protection and conservation of natural resources consistent with international conventions, agreements and treaties.

- Existence of several structures (public, para-state and private) for support and advice on natural resource management.

- Existence of many mechanisms and tools for planning and management of natural resources.

- Effectiveness of decentralization for the transfer of skills and powers of the State to regional authorities with a strong survival of freedom and democracy.

\subsection{Constraints and challenges}

Despite these tremendous opportunities and strengths, the Inland Niger Delta still faces the following challenges:

- Variability of rainfall conditions (reduction in rainfall, pockets of drought, late and early cessation of rains) and hydrological conditions (reduction of river flooding which has limited the surface of the flooded areas)

- $\quad$ Silting of the rivers

- Low agricultural, pastoral and fisheries productivity

- Lack of access to inputs and equipment (for packaging, storage and marketing of products) as well as the establishment of income generating activities by the rural population

- Transport and energy costs (for the processing of agricultural products) are very high, especially due to the isolation of the cercles and lack of electricity in the towns and villages

- Erosion of traditional self-help and solidarity systems

- High population growth rate fueled by high natural births and immigration

- A current dynamic that is developing around the land issue in rural areas, creating all kinds of confusion, speculation, conflicts and litigations, and the difficulties of applying the laws

- Weak coordination among development partners

- Deterioration of ecological conditions of the Inland Niger Delta.

All these contribute to the low productivity of the Delta. In terms of living conditions of rural populations, the situation is reflected in the persistence of food and economic insecurity of households and the worsening impoverishment of the IND. 


\subsection{Approaches to mitigate constraints and challenges}

- Refinement and improvement of promising planning tools and flood prediction mechanisms and disseminating the same to stakeholders for better planning of activities in the Delta

- Development of a natural resource management master plan for the Inland Niger Delta which identifies and monitors technical, scientific, social, environmental and climate change indicators

- Development of water control techniques necessary for development activities

- Conservation and preservation of natural resources and restoration of ecosystems

- Strengthening the capacities of actors, including civil society organizations

- Promotion of consultation, coordination and synergy among development actors. 


\section{REFERENCES}

A \& W EcologischOnderzoek, 2010. The Inner Niger Delta, will it dry up because of the climate change and use of water upstream?

Banzhaf M, 2005. Socioeconomic impacts of decentralized management of natural resources. The contribution of local agreements in the fight against poverty.

CILSS, 2005. Adapting to climate change in the Central Delta of the Niger River in Mali. Report of the support project to the adaptation capacity of the Sahel to climate change. Cissé S, 1989. Study on rural production systems in the $5^{\text {th }}$ region No. 02/89 DRSPR Dembele L, 1999. Analytical summary of models of flooding in the Inner Niger Delta of Mali. Ecole Normale Superieure - (College preparing teachers for higher education) (DER History and Geography). Bamako, Mali University: 58 p.

Diakite N, Sahel 2002. Consult: The management of pastoral resources in the $5^{\text {th }}$ region.

Diakite N, Sahel 2004. Consult: Adaptation of pastoralists to climate change in the Mopti region.

Diakite N, Sahel 2007. Consult: Historical development of the Inner Niger Delta.

Diakite N, Sahel 2010. Consult: The problem of management of pastoral resources in the Inner Niger Delta: Pasture, Issues, Challenges and Perspectives.

Djiré M, 2003. Local conventions, a tool for sustainable management of natural resources. Achievements and questions using examples from Mali. Communication at the workshop "How to secure land rights in rural areas." Forum Praia +9, Bamako, 2003.

Djiré M, 2004. Local conventions in Mali: a large legal amorphous grouping and a large pragmatism in NRM. Local conventions in the Sahel, No. 2.

DRP Mopti, O. Diarra 2011. The problems of fisheries in the Inner Niger Delta.

GDRN5, 2005: Report of the study on the problems of management of water resources in the Inner Niger Delta.

IPE- Mali, UNDP, 2009. Integrated Assessment of Ecosystems: Case of the Mopti Region in Mali.

IUCN/REDDIN, 2010. Rehabilitation project of degraded ecosystems in the Inner Niger Delta.

Kone sidiki, 2007. Inventory and analysis of land disputes and existing initiatives in the region of Mopti. Forum of the people of Sikasso.

Liersch S, Cools J, Kone B, Koch H, Diallo M, Aich V, Fournet S, Hattermann FF, 2012. Vulnerability of food production in the Inner Niger Delta to water resources management under climate variability and change, Submitted to Environmental Science and Policy

Mariko A, 2003. Characterization and monitoring of the dynamics of flooding and vegetation in the Inner Niger Delta (Mali) by remote sensing. PhD thesis. Montpellier II University, France.

MEA, Royal Haskoning, Altenburg \& Wymenga and GID-Mali, 2010. Current status of the Inner Niger Delta: Towards a common vision of development. 
MEA, Royal Haskoning, Altenburg \& Wymenga and GID-Mali, 2010. Sustainable development programme of the Inner Niger Delta (PPD-DIN);

MEA/GTZ, 2007. National Report on the State of the Environment in Mali.

MEA/GTZ/PADELIA, 2007. Collection of Texts on Environmental Law in Mali. National laws and international texts. Volume $1 \& 2$.

MEP/DNPI, 2011. Support Project for Livestock Development in the Mopti Region (PRODEM).

MEP, 2010. Master Plan for Development of fisheries and aquaculture, Bamako, Mali.

Ministry of Rural Development/CPS, 2001. Handbook of Statistics on the Rural Sector.

Mopti Regional Assembly, 2007. Strategic Development Plan of Mopti Region 2007 2017: Strategic Guidelines and Direction.

Mopti Regional Assembly, 2007. Strategic Development Plan of Mopti Region in 2007 2017: Regional Diagnosis: Strategic Guidelines and Direction.

Mopti Regional Assembly, 2011. Draft Regional Master Plan for Vocational and Technical Training and Employment (SDRFPTE).

National Directorate of Nature Conservation, 2008. Annual Report of Activities.

ODHD - UNDP/Mali, 2006. Poverty profile of the districts of Mali.

PAGEIT, 2006. Report of the studies on environmental impact of waterways on fisheries resources.

RIZA, WIS and Altenburg \& Wymenga, 2005. Niger, a lifeline/Efficient water management in the Upper Niger Basin.

Séroussi M. et al, 2003. Analysis of vulnerability and livelihood systems of rural households in the Mopti region.

Wetlands International, 2007. Flooded forests of the Inner Niger Delta in Mali.

Wymenga E, Koné B et al, 2008. Ecology and sustainable management of natural resources of the Inner Niger Delta.

Zwarts et al., 2005. Niger a Lifeline, to be downloaded from www.altwym.nl (see under publications, also French version).

Zwarts et al., 2009. Living on the edge. Birds and wetlands in a changing Sahel. KNNV publishers, Utrecht. 


\section{WORKING PAPERS}

2011

124. An assessment of farm timber value chains in Mt Kenya area, Kenya

125. A comparative financial analysis of current land use systems and implications for the adoption of improved agroforestry in the East Usambaras, Tanzania

126. Agricultural monitoring and evaluation systems

127. Challenges and opportunities for collaborative landscape governance in the East Usambara Mountains, Tanzania

128. Transforming knowledge to enhance integrated natural resource management, research, development and advocacy in the highlands of Eastern Africa

129. Carbon-forestry projects in the Philippines: potential and challenges: the Mt Kitangland range forest-carbon development

130. Carbon forestry projects in the Philippines: potential and challenges. The Arakan Forest Corridor forest-carbon project

131. Carbon-forestry projects in the Philippines: potential and challenges. The Laguna Lake Development Authority's forest-carbon development project

132. Carbon-forestry projects in the Philippines: potential and challenges. The Quirino forest-carbon development project in Sierra Madre Biodiversity Corridor

133. Carbon-forestry projects in the Philippines: potential and challenges. The Ikalahan ancestral domain forest-carbon development

134. The importance of local traditional institutions in the management of natural resources in the highlands of Eastern Africa

135. Socio-economic assessment of irrigation pilot projects in Rwanda

136. Performance of three rambutan varieties (Nephelium lappaceum L.) on various nursery media

137. Climate change adaptation and social protection in agroforestry systems: enhancing adaptive capacity and minimizing the risk of drought in Zambia and Honduras

138. Does value chain development contribute to rural poverty reduction? Evidence of asset building by smallholder coffee producers in Nicaragua

139. Potential for biofuel feedstock in Kenya

140. Impact of fertilizer trees on maize production and food security in six districts of Malawi.

2012

141. Fortalecimiento de capacidades para la gestión del Santuario Nacional Pampa Hermosa: Construyendo las bases para un manejo adaptativo para el desarrollo local. Memorias del Proyect

142. Understanding rural institutional strengthening: a cross-level policy and institutional framework for sustainable development in Kenya

143. Climate change vulnerability in agroforestry 
The World Agroforestry Centre is an autonomous, non-profit research organization whose vision is a rural transformation in the developing world where smallholder households strategically increase their use of trees in agricultural landscapes to improve their food security, nutrition, income, health, shelter, energy resources and environmental sustainability. The Centre generates science-base knowledge about the diverse role that trees play in agricultural landscapes, and uses its research to advance policies and practices that benefit the poor and the environment.

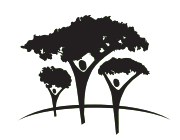

United Nations Avenue, Gigiri - PO Box 30677 - 00100 Nairobi, Kenya

Tel: +254207224000 or via USA +1 6508336645

Fax: +254 207224001 or via USA +16508336646

www.worldagroforestry.org 